\title{
Eutrophication Indexes Used as Fish Production Parameters in the Itaipu Reservoir (Brazil)
}

\author{
Rinaldo Antonio Ribeiro Filho ${ }^{1,2 *}$, Julia Myriam de Almeida Pereira ${ }^{2,3}$, Miguel Petrere Júnior ${ }^{4,5}$, \\ Simone Frederigi Benassi ${ }^{6}$
}

${ }^{1}$ Engenharia de Pesca, Universidade Estadual Paulista, Registro, Brazil; ${ }^{2}$ Núcleo de Estudos de Ecossistemas Aquáticos, Centro de Recursos Hídricos e Ecologia Aplicada, EESC, Universidade de São Paulo, São Carlos, Brazil; ${ }^{3}$ Departamento de Engenharia de Pesca e Aquicultura, Universidade Federal de Rondônia, Rua da Paz, Brazil; ${ }^{4}$ Programa de Pós Graduação em Diversidade Bilógica e Conservação, Universidade Federal de São Carlos (UFSCar), Sorocaba, Brazil; ${ }^{5}$ Programa de Pós Graduação em Sustentabilidade em Ecossistemas Marinhos e Costeiros, UNISANTA, Santos, Brazil; ${ }^{6}$ Divisão de Reservatório (MARR.CD), Itaipu Binacional, Foz do Iguaçu, Brazil.

Email: *rinaldo@registro.unesp.br

Received May $31^{\text {th }}, 2013$; revised June $29^{\text {th }}, 2013$; accepted July $6^{\text {th }}, 2013$

Copyright (C) 2013 Rinaldo Antonio Ribeiro Filho et al. This is an open access article distributed under the Creative Commons Attribution License, which permits unrestricted use, distribution, and reproduction in any medium, provided the original work is properly cited.

\begin{abstract}
The knowledge of liminology can be applied in studies of trophic state indexes and morfoedaphic indexes as factors for determining the inference fish production in reservoirs. This work is based on the hypothesis of the trophic cascade relations, particularly related to bottom-up and top-down effect in Itaipu Reservoir (Brazil). Using the data available by Itaipu, from 1999 to 2004, analyzes of multiple regressions were accomplished to determine the relationships of the dependent and independent variables. We applied the trophic state indices (TSI) based on readings Secchi disk, total phosphorus and chlorophyll-a density for obtaining TSI medium. Morfoedaphic index was calculated based on the reading of the concentration of dissolved solids and the inference of fishing yield, from this index. The average results of the trophic state indices indicate an oligotrophic status for the entire reservoir as well as for the riverine, transition and lacustrine zones separately. The fish was yieldn Estimated by the relation with cyanobacteria concentration, and this was the best variable que explained this prediction. The use of the morfoedaphic index (MEI), with the recorded catch data, predictive models can generate que estimate the fishing yield in the Itaipu Reservoir. The relations of MEI with chlorophyll-a and water transparency que Indicate this index may be a good predicting factor for future fish captures.
\end{abstract}

Keywords: Trophic Cascade Reservoir; Limnology; Biotic Community; Fish Yield

\section{Introduction}

\subsection{Relationship between Fish and Water Quality}

Fish play an important role in the biocenosis of reservoirs when it comes to water quality. The presence or absence of certain species, together with the amount of fish in the system help to determine the composition and quantity of nutrients, zooplankton and phytoplankton in reservoirs [1].

The ichthyofauna of a reservoir is altered according to water quality owing to two factors: 1) contamination by

*Corresponding author. pollutants from tributaries, what can affect various parts of the reservoir and 2) changes in how the hydrological system works [1]. The composition of species of the fauna depends largely on geographical characteristics and lakes and reservoirs are characterized by the absence of true pelagic species, and most of the reservoirs are populated by species that typically inhabit the coastal region.

\subsection{Trophic Cascade Interactions in Reservoirs}

The trophic cascade theory in lakes and reservoirs is based on two principles: 1) loss of energy between a trophic level and another and 2) disturbance of a trophic level with consequences in the remaining trophic levels. 
The pioneer work of [2] was responsible for highlighting the effect of fish on the structure of the aquatic food chain. After a few years, research such as $[3,4]$ contributed to the development of the food web theory in lakes, revealing the important role of fish, ignored for decades in the field of limnology.

The theory of trophic cascades [5]; see critiques from $[6]$ and the meta-analyses of $[7,8]$ and the bottom-up/topdown theory [9] are the two main conceptual models of work used here. Phytoplankton responds positively to nutrient enriched systems with an odd number of trophic levels (three levels: phytoplankton, zooplankton and planktivorous fish), but not in systems with an even number of trophic levels (two levels without fishes, or four levels with piscivorous fishes).

The effect of the stock of planktivorous fish on the zooplankton community has been well studied [10-12] and there is strong pressure of these fish on the biomass of algae [13,14]. The effect of piscivorous fishes in a system has a strong relationship with the stock of planktivorous fishes, causing the drastic reduction of latter [6, 15,16]. Some studies confirm that the impact of fish stocks favors the concentrations of chlorophyll through the excretion of nutrients and the predation of zooplankton [17-20]. With regard to the stock of piscivorous fishes, many studies were not successful [6,17], mainly due to the low stocking density [21]. In many studies the top-down effect was observed [4,5,13,15,25-29].

[25] suggest that knowing how the food chain works can be useful for the management of aquatic ecosystems aiming at ecology conservation. The increase of piscivorous fishes may decrease the density of planktivorous ones and, consequently, increase grazing and depletions in the concentrations of chlorophyll-a. The increase in the stock of piscivorous can be a tool for rehabilitating eutrophic lakes. The concept of trophic cascade with links between limnology and fisheries biology suggests a biological alternative for lake management.

Studies by [7] prove the theory of trophic cascade. They noted that the manipulation of fish communities can be used to control algal biomass, but these relationships are fragile. The authors mention that the control of the phytoplankton through the trophic cascade management (biomanipulation) can be successful in about 60\% of the cases and that the reduction zooplanktivorous species would result in a slight reduction in phytoplankton biomass and hence a small improvement in the quality of water.

[30] mention that the top-down control of chlorophylla occurs according to the following conditions: 1) shortterm experiments, 2) shallow lakes with macrophytes and 3) deep slightly eutrophic or mesotrophic lakes. Other experiments indicate that top-down control may be unlikely in the following conditions: 4) eutrophic or hyper- trophic deep lakes, unless there is severe limitation of light, and 5) for all lakes when there is extreme nutrient limitation (oligotrophic and ultra-oligotrophic lakes). Important factors that are responsible for the top-down control under the described conditions in 1) and 3) are the time scales that prevent the slow development of phytoplankton; shallow depths allow macrophytes to become dominant primary producers 2), and biomanipulation induced reduction of phosphorus (P) available to phytoplankton 3).

[31] compared the data of trophic (limnological) variables with the spatial and temporal distribution of fishes, zooplankton and phytoplankton. According to the analysis (meta-analysis), the distribution of the studied trophic levels was correlated with the temperature of water and nutrient concentration distributions.

\subsection{Tropical and Subtropical Trophic Cascades}

According to [32], the dams in the semi-arid Northeastern region of Brazil offer excellent opportunities for theoretical comparisons on the relative importance of the top-down and bottom-up impact structuring forces on the fish-plankton interactions in tropical environments, including comparisons between the effects of the dominance of omnivorous and low number of piscivorous species. However, most of the dams have never been studied, except for some large public ponds, especially those controlled by DNOCS-Departamento Nacional de Obras Contra a Seca (National Department of Works Against Droughts) in the states of Ceará and Paraíba. Regional reports on fishery yield, hydrochemistry and limnology (e.g. [33-41]) were rare. The author points out that to make generalizations it is more appropriate to use a comparative approach based on data from climatology, limnology and plankton communities and fish collected in the reservoir, and studies correlating all these variables are in small number $[42,43]$. Studies with this type of approach can provide important practical and social implications for predictive limnology [44], for the management of fishery yield [45] and/or water quality.

While studying 31 Argentinean reservoirs, [46] have shown that in environments in which the effect of piscivorous stock did not cause a depletion of zooplanktivores, the phytoplankton biomass reduced drastically. The authors emphasized that human influence can cause changes in trophic relationships in lakes and reservoirs.

[47] evaluated the top-down and bottom-up effects in a floodplain lake in Bolivia. The authors found two types of effects on the trophic cascade in experiments in mesocosms, and the effect of these relationships varied among trophic levels. The effect of planktonic fishes did not show any positive relationship with zooplankton, mainly with cladocerans, and phytoplankton showed bottom-up effect. 
The objectives of this work were to evaluate the water quality of the Itaipu Reservoir (central body and arms of the left bank of the reservoir) through the analysis of physical, chemical and biological variables, given the multiple uses of the reservoir during the period from 1999 to 2004; to analyze the evolution of the trophic levels of the reservoir, including its left margin arms, and characterize the trophic webs and the relationship between the relative fish biomass, plankton and limnology of the Itaipu reservoir.

\section{Materials and Methods}

\subsection{Characterization of the Study Area}

The Paraná River is the tenth longest river in the world (4695 km), and was considered the most important hydrological system of the La Plata River Basin [48]. It is formed by the confluence of the rivers Grande and Parnaíba (center-south of Brazil), flowing into La Plata River, North of Argentina [49]. The Paraná River Basin is responsible for more than $70 \%$ of hydroelectric power production in Brazil, has the largest population density in South America and includes other major rivers, such as the rivers Grande, Tietê, Parnaíba, Paranapanema, and Iguaçu, were approximately 130 dams were constructed (Figure 1).

The Itaipu Reservoir, completed in October 1982, is located in the Brazil-Paraguay border, between latitudes $24^{\circ} 05^{\prime} \mathrm{S}$ and $25^{\circ} 33^{\prime} \mathrm{S}$ and between longitudes $54^{\circ} 00^{\prime} \mathrm{W}$ and $54^{\circ} 37^{\prime} \mathrm{W}$ (Grw). It has a surface of $1350 \mathrm{~km}^{2}$ in its mean elevation of operation $(220 \mathrm{~m})$ and $1.460 \mathrm{~km}^{2}$ when in maximum height $(223 \mathrm{~m})$. Of these, $625 \mathrm{~km}^{2}$ are part of Brazil and $835 \mathrm{~km}^{2}$ of Paraguay. It stretches over $151 \mathrm{~km}$ (170 km in maximum quote) and separates the cities of Guairá-Salto del Guayra and also Foz do IguaçuCiudad del Este [50].

With an average depth of $22 \mathrm{~m}$, and possible depths of $170 \mathrm{~m}$ near the dam, the Itaipu reservoir accumulates as normal maximum volume, $29,109 \mathrm{~m}^{3}$ of water. The residence time in the main channel is 29 days and the speed of the water can reach $0.6 \mathrm{~m} / \mathrm{s}$. The average residence time is, however, 40 days. It operates with a maximum annual level variation of $0.6 \mathrm{~m}$ [51].

Energy production is the main use of the Itaipu reservoir, which was the primary motivation for its construction. However, other secondary uses are currently coming into scene, especially 1) navigation, facilitated by the drowning of The Sete Quedas Falls (Guaira), 2) recreation and tourism, mainly in five artificial beaches built on its banks, 3) water supply for cities and irrigation of smallholdings and 4) professional fishing [52].

Based on Carlson's trophic state index (phosphorus and chlorophyll-a), this reservoir was classified as mesotrophic, and some eutrophic areas may be found in its arms during certain periods of the year. It presents an annual cycle of thermal stratification in its main body (spring-summer), which classifies it as a monomictic hot lake, besides daily stratification processes in its arms.

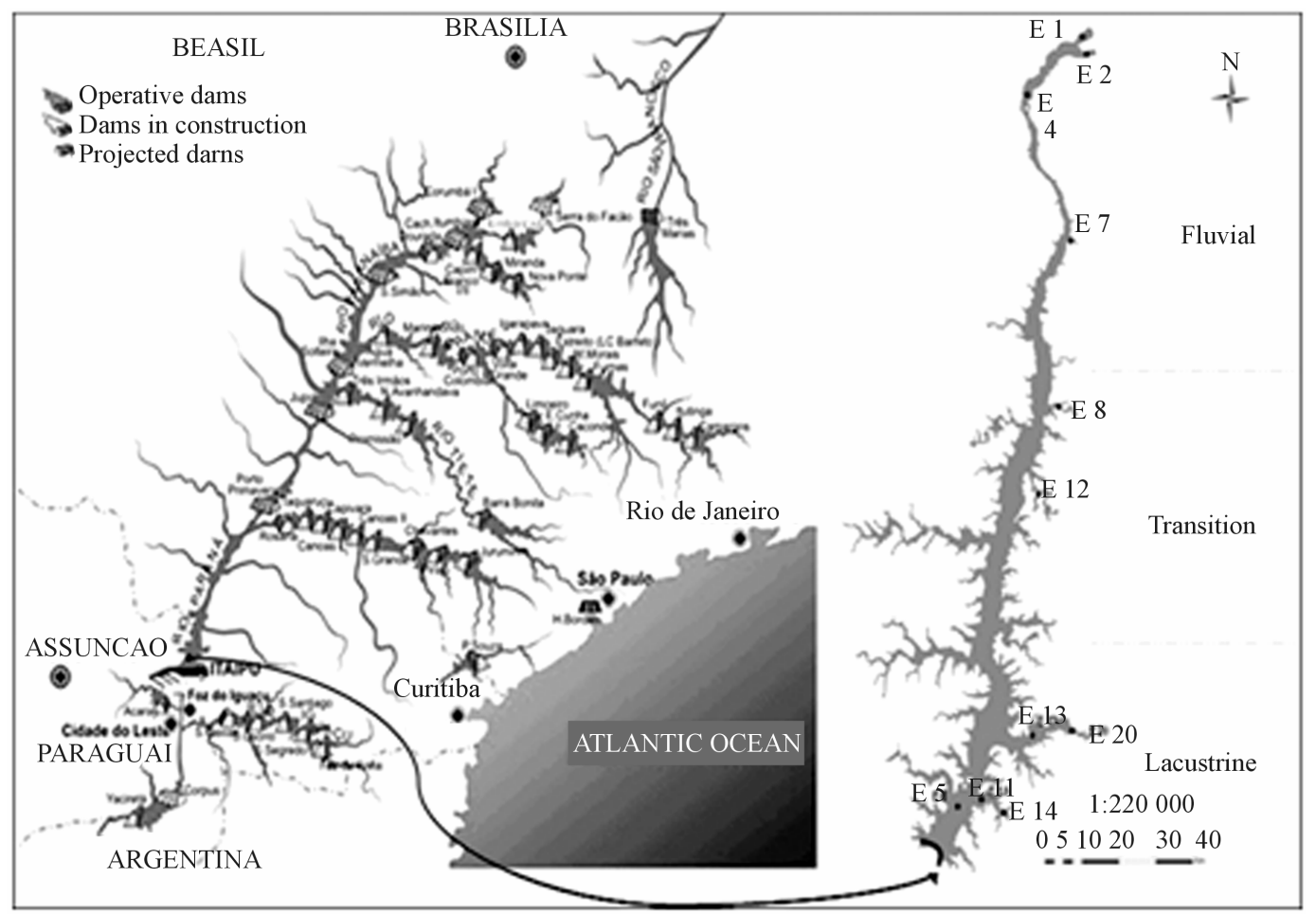

Figure 1. The Paraná River basin, with its reservoirs (Source: Itaipu Binacional, 2006). 
The fish assemblage of the Itaipu reservoir and its catchment area is composed of 114 species in all environments. The dominant species vary with the type of environment, because this is a factor that contributes significantly to the structure of this assemblage (ANNUAL REPORT ITAIPU BINACIONAL).

\subsection{Characterization of the Sampling Stations}

To establish the location of the sampling stations we considered the compartmentalization of the Itaipu Reservoir, which is composed by three horizontal regions, along the main body of the reservoir [50,53-55]: 1) the riverine zone: located at the beginning of the reservoir, 2) the transition region: between the lotic and lentic regions, and 3 ) the lentic region, called "lacustrine region", where the reservoir is usually deeper and wider.

Furthermore, the Itaipu Reservoir has a dendritic form, what means that attached to its central body there are branches on the sides called reservoir arms which present systems that are almost independent from the main body system and that have their own particular characteristics. Due to this compartmentalization, a network of water quality monitors was established, totaling twelve sampling stations (Figure 2).

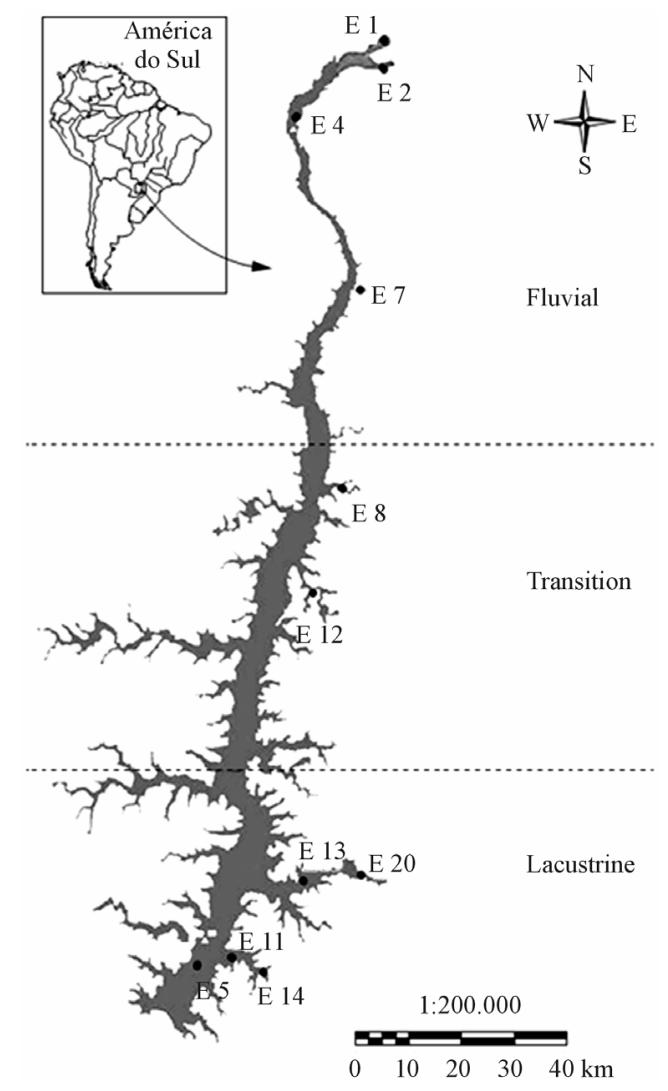

Figure 2. Morphometry and sampling sites in the Itaipu Reservoir, with the riverine, transition and lacustrine zones adopted in the monitoring program.
Stations E1, E2, E3, and E7, in areas of lotic characteristics are in the riverine zone. Stations E5, E11, E12, E14 and E20 are in the lacustrine region and stations E8 and E12 are in the transition region.

\subsection{Data Collection}

The data analyzed in this study were provided by Itaipu Binacional. Limnological analyses, including physical and chemical water variables, phytoplankton and zooplankton were made by Instituto Ambiental do Paraná (IAP), the Environmental Institute of Paraná, based on quarterly collections, between 1999 and 2004. Information on fish stocks are from the studies conducted by Núcleo de Pesquisa em Limnologia, Ictiologia e Aquicultura (NUPELIA/UEM), the Center for Research in Limnology, Ichthyology and Aquaculture.

According to [54], samples were collected at the water surface, and the physical, chemical and biological water quality variables were monitored in all field samplings. The following variables were measured in the field: temperature, dissolved oxygen concentration and percentage of saturation, $\mathrm{pH}$, electrical conductivity and water transparency. Other physical and chemical variables, such as alkalinity, total nitrogen Kjeldahl (TKN) nitrate, nitrite, ammonia and nitrogen, total solids, suspended solids, BOD, COD and total phosphorus were analyzed in the laboratory, according to [56], as well as the concentration of chlorophyll-a [57]. The analysis protocols were presented by [58].

The climatological data were obtained from weather stations in the cities of Guaira (riverine area), Entre Rios do Oeste (transition zone) and Iguazu Falls (lacustrinedownstream zone).

Data on fishes were grouped into trophic guilds, according to [55]. They presented the relative densities, calculated from numerical abundance in kilograms, corresponding to the weight of gutted fish without a head.

The relative abundance of phytoplankton, zooplankton and fish were presented according to the regions (riverine, transition and lacustrine) of the reservoir to enable the comparison of the spatial distribution patterns.

\subsection{Statistical Analysis of Data}

To test the trophic cascade hypothesis in the reservoir we performed linear regression analyses among the physical, chemical, biological and trophic guilds, and trophic levels were analyzed one by one, determining the interactions between them. These analyses were performed in accordance with food web models (Top down and Bottom up) $[9,18,24,32]$. The graphs were evaluated to determine whether the relationships were linear or not. To stabilize the variance, the neperian logarithms were taken for all limnological variables. Graphically, limnological 
variables were expressed according to the equation below:

$$
\ln v a r=\ln (v a r+1)
$$

where var is the original value of the limnological variable Invar is the transformed the value of var.

For biotic variables, in order to minimize null values, the transformation was performed according to the following equation, based on absolute numerical abundance:

$$
\ln \text { bio }=\ln (\text { bio }+1)
$$

where bio is the original value of the biotic variable +1 , In bio is the transformed value of bio.

In the analysis of residues, assumptions of linearity, normality and homoscedasticity were confirmed.

To test the effect of limnological and fish biomass on chlorophyll-a and cyanobacteria we carried out multiple regression analyses following the stepwise procedure, in which all variables were tested, and as they did not produce any significant results, they were one by one discarded from the model.

To test the hypothesis that the chlorophyll-a, and therefore the productivity of the reservoir, depends on the concentration of nutrients, a multiple regression analysis was performed. The concentration of chlorophyll-a was considered a dependent variable, and was plotted with the forms of nutrients (independent variable), and only those that showed significant results remain present in the final model.

In order to detect possible relationships between the biotic and abiotic variables we carried out multiple regression analyses. These used the densities of cyanobacteria, the concentration of total phosphorus and biomass of fishes (omnivores and detritivores) as dependent variables, what turned out to be of relevance in the linear regression analyses performed. The analyses follow the same protocol of the abiotic variables analyses.

\subsection{Trophic State Index (TSI)}

In order to assess the trophic state of the Itaipu Reservoir, we used the trophic state index proposed by Carlson and modified by [59], as described below:

$$
\operatorname{TSI}(\text { Secchi })=10\left[6-\left(\frac{0.64+\ln (\text { Secchi })}{\ln 2}\right)\right]
$$

$$
\operatorname{TSI}(\text { total } P)=10\left[6-\left(\frac{\ln \left(\frac{80.32}{\text { total } P}\right)}{\ln 2}\right)\right]
$$

To determine TSI (mean), the calculation of the index was done using the weighted average by assigning a lower weight to the transparency of water, as suggested by [59]. Thus, to calculate the TSI (mean), we used the following formula:

\subsection{Estimate of Fishing Yield}

Through Morfoedaphic Index (MEI) of [60], we estimated fishing yield and the MEI was expressed by the following equation:

$$
\mathrm{MEI}=\frac{\mathrm{TDS}}{\mathrm{Zm}} \quad \text { (7) or } \mathrm{MEI}=\frac{\text { conductivity }}{\mathrm{Zm}}
$$

where TDS $=$ concentration of dissolved solids $(\mathrm{mg} / \mathrm{L})$ and $\mathrm{Zm}=$ average depth $(\mathrm{m})$.

\subsection{Inference of Fishing Yield}

In order to estimate the fishing yield of the Itaipu reservoir and verify if the predicted index values were significant we used the equation proposed by [61], with the model derived from a capture data regression analysis and MEI (morfoedaphic index):

$$
\mathrm{FY}=4.1 * \mathrm{MEI}^{0.8}
$$

The index below (MEI) is a relationship between the concentration of dissolved solids in water divided by the mean depth of the lake or reservoir, and was first used by [60] to estimate the fishing yield of African lakes. [62] found that a better fit could be obtained for MEI expressed as the relation between conductivity and the average depth:

$$
\mathrm{MEI}=\frac{\text { conductivity }\left(\mu \mathrm{S} * \mathrm{~cm}^{-1}\right)}{\text { average depht }(\mathrm{m})}
$$

\section{Results}

\subsection{Relationships between the Limnological Variables}

The analysis shows that the TKN and total phosphorus

$$
\begin{gathered}
\operatorname{TSI}(\text { Chlorophyl })=10\left[6-\left(\frac{2.04-0.695 * \ln \text { Chlorophyl }_{a}}{\ln 2}\right)\right] \\
\operatorname{TSI}(\text { mean })=\frac{\operatorname{TSI}(\text { Secchi })+2\left[\operatorname{TSI}(\text { total P })+\operatorname{TSI}\left(\text { Chlorophyl }_{a}\right)\right]}{5}
\end{gathered}
$$


acted positively to the development of chlorophyll-a concentrations, and the variables ammonia nitrogen and nitrate showed negative relationships with the variable. These results demonstrate the importance of nutrients in

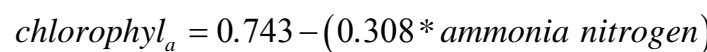

Analysis for testing the relationship between water transparency and other forms of nutrients which help to increase the concentration of chlorophyll-a was of the stepwise type, where the variables that show $p>0.05$ are successively discarded from the model (Table 2). The final multiple regression model explains $30 \%$ of the variability of chlorophyll-a $\left(\mathrm{R}=0.550, \mathrm{R}^{2}=0.302, \mathrm{~F}=\right.$ $39.586, \mathrm{~N}=278, \mathrm{P} \leq 0.05$ ), being expressed by the model below. According to this analysis, the concentration of chlorophyll-a (dependent variable) can be explained by a linear combination of independent variables, indicating that all the variables tested contributed to the develop-

$$
\log \text { chlorophyl }_{a}=0.698-(0.484 * \log \text { Secchi })+(0.626 * \log \mathrm{TKN})+(0.170 * \log \mathrm{COD})+(0.462 * \log \mathrm{BOD})
$$

To prove the effects of water transparency on the productivity of the reservoir, a multiple regression analysis was performed to identify independent variables that are significantly correlated with water transparency (Table 5). The result of this analysis demonstrates the importance of independent variables tested on water transparency. These responses explain $61 \%$ of the relationship

$$
\begin{aligned}
\ln \text { cyanobacteria }= & 0.700+(1.536 * \text { lnchlorophyl })+(1.518 * \ln \text { Secchi }) \\
& +(0.417 * \ln \text { turbidity })-(0.501 * \operatorname{lnsuspended~solids~})+(3.420 * \ln T K N)
\end{aligned}
$$

\subsection{Trophic State Index}

Figure 3 shows the values of the weighted average (Secchi disk, chlorophyll-a and total phosphorous) of Trophic State Index. The transition zone showed the highest average (49.44), with the highest value (69.67) in August 2001. The riverine zone presented an average of 52.19, with the lowest value (34.08) in November 2003. The lacustrine zone had the lowest average among the zones of the reservoir, with an average of 36.02.

The calculation of TSI average for the entire reservoir was 45.40 , what can be classified as mesotrophic. This value, however, is near the threshold value of the oligotrophic waters classification ( $\geq 44)$.

\subsection{Density and Relative Abundance of Phytoplankton}

Figure 4 shows the relative abundance of phytoplankton in the Itaipu Reservoir. Cyanobacteria were abundant in the whole system, comprising $76 \%$ of the total. In the transition zone relative abundance was $90 \%$ whereas in the riverine zone it was $65 \%$. The diatoms corresponded to the second most abundant group, with $14 \%$ of the total. In the riverine zone we obtained the greatest concentration $(23 \%)$ and the smallest contribution was in the transition zone (7\%). Chlorophyceae accounted for $5 \%$, being more abundant in the riverine zone $(9 \%)$ and less abundant in the transition zone $(2 \%)$. The same pattern

Table 1. Results of multiple regression analysis assessing the effect of ammonia nitrogen, TKN, nitrate and total $P$ variables on concentrations of chlorophyll-a in the Itaipu Reservoir, for the period from 1999 to 2004.

\begin{tabular}{ccccccc}
\hline & Coefficient & Std. Error & T & P & VIF \\
\hline Constant & 0.743 & 0.193 & 3.852 & $<0.001$ & \\
Ammonia Nitrogen & -0.308 & 0.108 & 2.838 & 0.005 & 1.101 \\
TKN & 0.755 & 0.0845 & 8.940 & $<0.001$ & 1.150 \\
Nitrate & -0.184 & 0.095 & -1.923 & 0.056 & 1.004 \\
P total & 0.189 & 0.0691 & 2.733 & 0.007 & 1.082 \\
\hline
\end{tabular}


Table 2. Results of multiple regression analysis assessing the effect of water transparency, TKN and ammonia nitrogen variables on concentrations of chlorophyll-a in the Itaipu Reservoir for the period from 1999 to 2004.

\begin{tabular}{cccccc}
\hline & Coefficient & Std. Error & T & P & VIF \\
\hline Constant & 0.651 & 0.156 & 4.160 & $<0.001$ & \\
Transparency & -0.505 & 0.111 & -4.566 & $<0.001$ & 1.020 \\
Ammonia Nitrogen & -0.241 & 0.106 & -2.268 & 0.024 & 1.098 \\
TKN & 0.749 & 0.0814 & 9.200 & $<0.001$ & 1.11 \\
\hline
\end{tabular}

Table 3. Results of multiple regression analysis assessing the effect of water transparency, TKN, BOD and COD on concentrations of chlorophyll-a in the Itaipu Reservoir, for the period from 1999 to 2004.

\begin{tabular}{cccccccc}
\hline & Coefficient & Std. Error & T & P & VIF \\
\hline Constant & 0.698 & 0.0797 & 8.756 & $<0.001$ & \\
Water transparency & -0.484 & 0.108 & -4.497 & $<0.001$ & 1.026 \\
TKN & 0.626 & 0.0776 & 8.068 & $<0.001$ & 1.074 \\
COD & 0.170 & 0.0835 & 2.040 & 0.042 & 1.188 \\
BOD & 0.462 & 0.138 & 3.347 & $<0.001$ & 1.242 \\
\hline
\end{tabular}

Table 4. Summary of results of multiple regression analysis assessing the effect of $P$ total and omnivores variables on concentrations of cyanobacteria in the Itaipu Reservoir.

\begin{tabular}{ccccccc}
\hline & Coefficient & Std. Error & T & P & VIF \\
\hline Constant & 17.622 & 2.499 & 7.053 & $<0.001$ & \\
$\log$ total phosphorous & 45.331 & 20.048 & 2.261 & 0.043 & 1.003 \\
log Omnivores & -2.883 & 0.493 & -5.849 & $<0.001$ & 1.003 \\
\hline
\end{tabular}

Table 5. Results of multiple regression analysis assessing the effect of variables ammonia nitrogen, chlorophyll-a, turbidity, TKN, total suspended solids, BOD and total phosphorous on the water transparency in the Itaipu Reservoir, for the period from 1999 to 2004.

\begin{tabular}{|c|c|c|c|c|c|}
\hline & Coefficient & Std. Error & $\mathrm{t}$ & $\mathrm{P}$ & VIF \\
\hline Constant & 0.337 & 0.0728 & 4.627 & $<0.001$ & \\
\hline Ammonia nitrogen & 0.0820 & 0.0383 & 2.141 & 0.033 & 1.197 \\
\hline Chlorophyl-al & -0.0724 & 0.0213 & -3.401 & $<0.001$ & 1.491 \\
\hline Turbidity & -0.236 & 0.0250 & -9.466 & $<0.001$ & 1.380 \\
\hline TKN & 0.0971 & 0.0332 & 2.921 & 0.004 & 1.549 \\
\hline Suspended solids & -0.210 & 0.0254 & -8.273 & $<0.001$ & 1.370 \\
\hline BOD & 0.184 & 0.0497 & 3.691 & $<0.001$ & 1.270 \\
\hline Total phosphorous & -0.145 & 0.0248 & -5.852 & $<0.001$ & 1.210 \\
\hline
\end{tabular}

was found for the phytoflagellates with a frequency of $5 \%$ for the whole reservoir, with greatest abundance recorded in the area lacustrine zone (7\%) and lowest in the transition zone $(2 \%)$.

\subsection{Density and Relative Abundance of Zooplankton}

The relative abundance of the zooplankton groups can be seen in Figure 5. Copepods were abundant in the entire reservoir, and in the lacustrine zone we obtained its highest value $(58 \%)$. In the transition zone abundance was $54 \%$ and in the riverine zone $42 \%$. The rotifers corresponded to the second most abundant group, with $32 \%$ for the entire reservoir. In the riverine zone we obtained the highest value (44\%), in the transition zone $28 \%$, and in the lacustrine zone we verified the lowest relative 


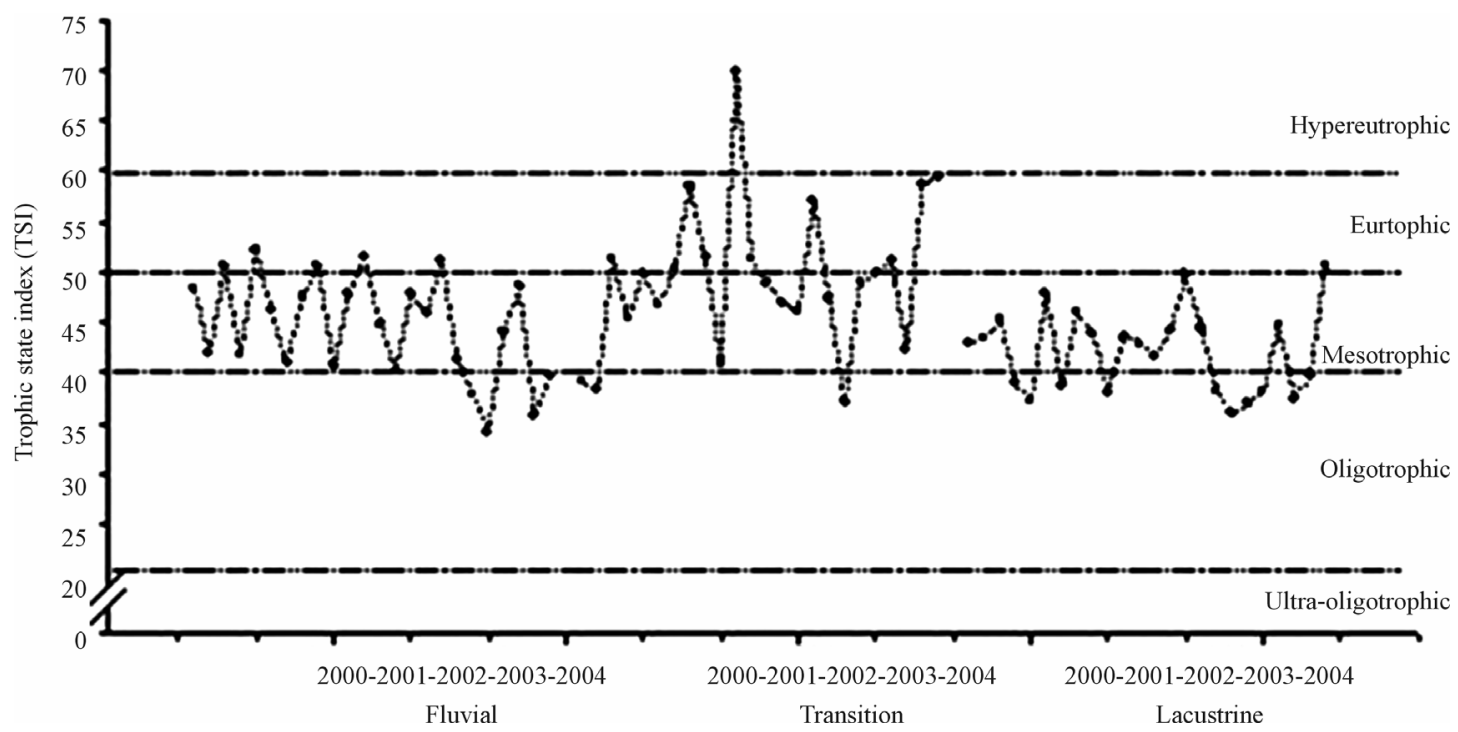

Figure 3. TSI variation (average) in the Itaipu Reservoir for the period from 1999 to 2004.

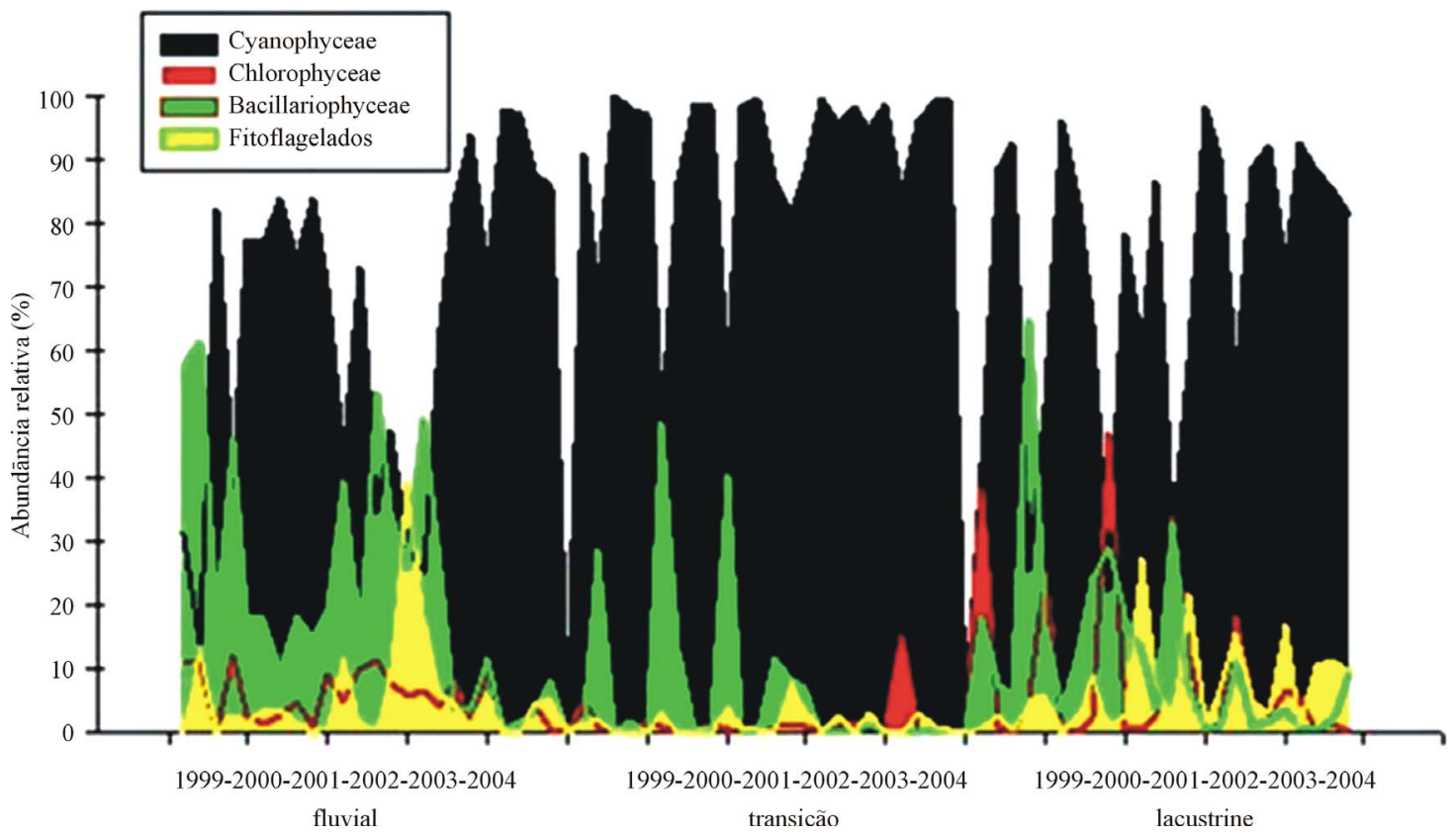

Figure 4. Variation of the relative abundance of phytoplankton according to the zones of the Itaipu Reservoir for the period from 1999 to 2004

abundance (25\%).

Cladocerans showed the lowest relative abundance throughout the whole reservoir, with $17 \%$. The highest abundance was in the transition zone (18\%), similar to the lacustrine zone $(17 \%)$, with the smallest contribution occurring in the riverine zone (14\%).

\subsection{Fishes}

Figure 6 shows the relative abundance of groups of fishes in the riverine, transition and lacustrine zones of the Itaipu Reservoir. The omnivores were the most abun- dant group throughout the reservoir, with $47.2 \%$, followed by piscivores $(30.5 \%)$, zooplanktivores $(8.5 \%)$, detritivores $(6.2 \%)$, iliophagous $(5.7 \%)$ benthivores $(1.1 \%)$, insectivores $(0.5 \%)$ and herbivores $(0.3 \%)$. In the lacustrine zone omnivores were more abundant $(71.8 \%)$, followed by detritivores (14.9\%) and piscivores $(8.7 \%)$. The other groups showed low abundance, and no presence of benthivores was recorded in this region. The transition zone also showed a higher relative abundance of omnivores (38.3\%), followed by piscivores (37.2\%). The iliophagous had $11.2 \%$ of relative abundance, fol- 


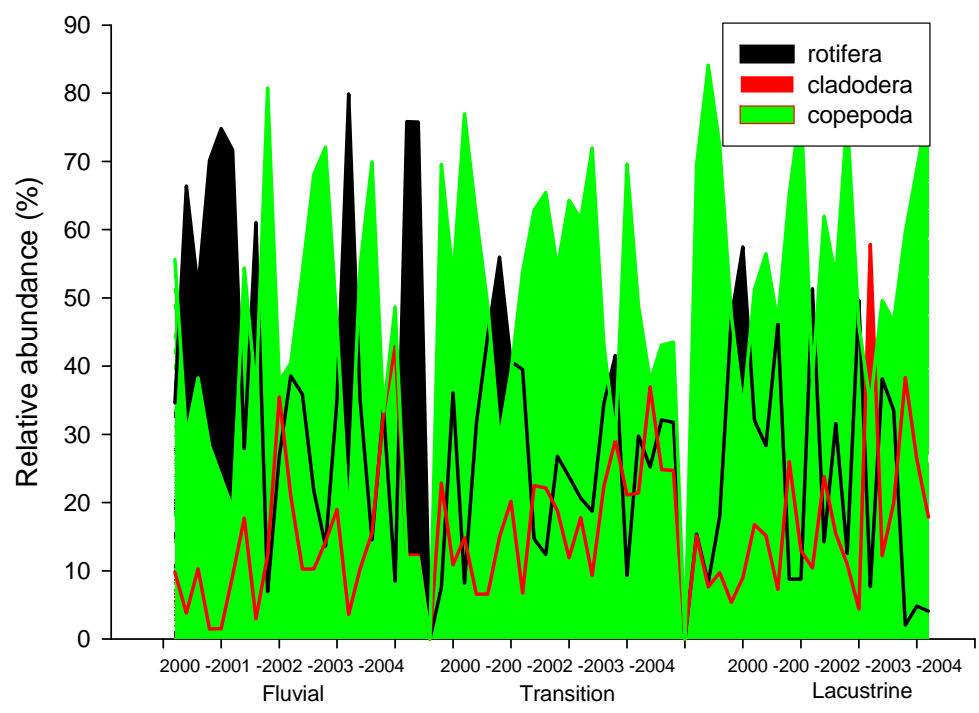

Figure 5. Variation of the relative abundance of zooplankton according to zones of the Itaipu Reservoir for the period from 1999 to 2004.

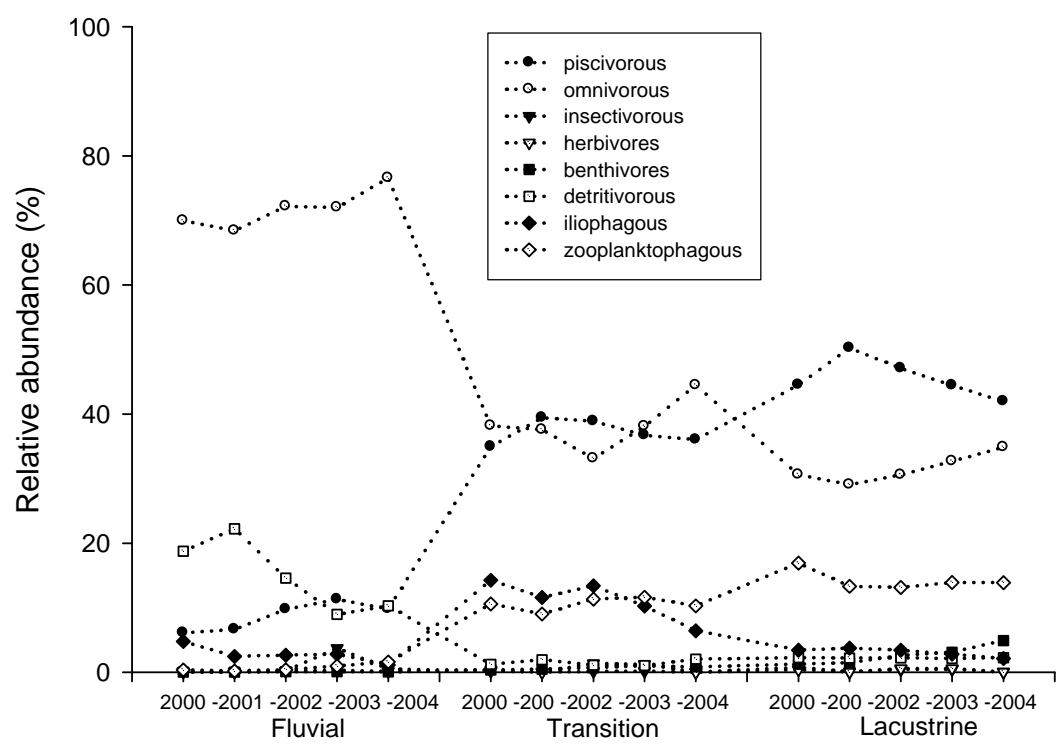

Figure 6. Variation of the relative abundance of fish trophic guilds according to zones of the Itaipu Reservoir for the period from 2000 to 2004.

lowed by zooplanktivores $(10.6 \%)$, detritivores $(1.4 \%)$, benthivores $(0.7 \%)$, herbivores $(0.6 \%)$ and insectivores $(0.1 \%)$. In the lacustrine zone the highest relative abundance pertained to piscivores (45.6\%), followed by omnivores $(31.5 \%)$, zooplanktivores (14.2\%), iliophagous (3.1\%), benthivores $(2.7 \%)$, detritivores $(2.2 \%)$ and, finally, herbivores and insectivores $(0.3 \%)$.

\subsection{Analysis of Trophic Interactions in the Itaipu Reservoir: Direct Effects}

Table 6 shows the negative impact of suspended solids concentration and turbidity on the Secchi disk value. In other words, the higher the concentrations of these vari- ables, the lower are the values of the Secchi disc reading, and consequently, of water transparency.

To test the trophic cascade hypothesis in the reservoir we performed linear regression analyses, checking the trophic levels one by one, thus determining the interactions between them (Table 6).

The omnivorous fishes showed to be negatively dependent on the piscivores, that is, the higher the piscivore biomass is, the lower the omnivore biomass will be. The benthivores were dependent on piscivores (positively) and negatively dependent on omnivores. The detritivores were dependent on omnivores (positive relationship) and negatively dependent on piscivores. The zooplanktivo- 
Table 6. Models of linear regressions performed and their respective values of $R^{2}, R, F$ and $P$.

\begin{tabular}{|c|c|c|c|c|c|}
\hline Models of linear regressions & Effect & $\mathrm{R}^{2}$ & $\mathrm{R}$ & $\mathrm{F}$ & $\mathrm{P}$ \\
\hline $\log$ secchi $=0.287-(0.368 * \log$ suspended solids $)$ & - & 0.412 & 0.642 & 200,607 & $<0.001$ \\
\hline $\log \operatorname{secchi}=0.390-(0.345 * \log$ turbidity $)$ & - & 0.372 & 0.610 & 169,063 & $<0.001$ \\
\hline $\log$ omnivores $=7.241-(0.452 * \log$ piscivores $)$ & - & 0.624 & 0.790 & 21,544 & 0.000 \\
\hline $\log$ benthivores $=-8.618+(2.410 * \log$ piscivores $)$ & + & 0.875 & 0.935 & 90,620 & 0.000 \\
\hline $\log$ detritivores $=9.516-(1.154 * \log$ piscivores $)$ & - & 0,565 & 0.752 & 16,896 & $<0.001$ \\
\hline $\log$ zooplanktivores $=-5.077+(1.899 * \log$ piscivores $)$ & + & 0.904 & 0.951 & 122,815 & 0.000 \\
\hline $\log$ benthivores $=21.538-(3.663 * \log$ omnivores $)$ & - & 0.662 & 0.813 & 25,419 & $<0.001$ \\
\hline $\log$ detritivores $=-9.124+(2.583 * \log$ omnivores $)$ & + & 0.928 & 0.963 & 166,702 & $<0.001$ \\
\hline $\log$ zooplanktivores $=19.857-(3.117 * \log$ omnivores $)$ & - & 0.797 & 0.893 & 51,156 & $<0.001$ \\
\hline $\log$ copepoda $=-2.721+(1.739 * \log$ iliophagous $)$ & + & 0.583 & 0.763 & 18,169 & $<0.001$ \\
\hline $\log$ cladocera $=-2.493+(1.569 * \log$ iliophagous $)$ & + & 0.610 & 0.781 & 20,344 & $<0.001$ \\
\hline $\log$ chlorophyll-a $=-0.274+(0.303 * \log$ cladocera $)$ & + & 0.301 & 0.549 & 6901 & 0.018 \\
\hline $\log$ chlorophyll-a $=-0.0155+(0.209 * \log$ copepoda $)$ & + & 0.186 & 0.431 & 3657 & 0.074 \\
\hline $\log$ chlorophyll-a $=0.563+(29.689 * \log$ P.total $)$ & + & 0.162 & 0.402 & 3084 & 0.098 \\
\hline $\log$ chlorophyll-a $=6.145-(1.029 * \log$ omnivores $)$ & - & 0.319 & 0.565 & 6082 & 0.028 \\
\hline $\log$ chlorophyll-a $=1.699-(0.294 * \log$ insectivores $)$ & - & 0.364 & 0.603 & 7436 & 0.017 \\
\hline $\log$ chlorophyll-a $=2.573-(0.415 * \log$ detritivores $)$ & + & 0.372 & 0.610 & 7696 & 0.016 \\
\hline $\log$ cyanobacteria $=-2.354+(0.808 * \log$ iliophagous $)$ & + & 0.537 & 0.733 & 15,067 & 0.002 \\
\hline $\log$ P.total $=0.0234-(0.00442 * \log$ insectivores $)$ & - & 0.453 & 0.673 & 10,770 & 0.006 \\
\hline $\log$ P.total $=0.0169-(0.00243 * \log$ herbivores $)$ & - & 0.443 & 0.665 & 10,323 & 0.007 \\
\hline $\log$ cyanobacteria $=17.850-(2.823 * \log$ omnivores $)$ & - & 0.658 & 0.811 & 24,980 & $<0.001$ \\
\hline $\log$ cyanobacteria $=4.969-(0.543 * \log$ insectivores $)$ & - & 0.341 & 0.584 & 6725 & 0.022 \\
\hline $\log$ cyanobacteria $=7.750-(1.060 * \log$ detritivores $)$ & - & 0.667 & 0.817 & 26,042 & $<0.001$ \\
\hline $\log$ cyanobacteria $=1.167+(0.586 * \log$ zooplanktivores $)$ & + & 0.346 & 0.588 & 6864 & 0.021 \\
\hline $\log$ cyanobacteria $=-0.349+(0.359 * \log$ cyanobacteria $)$ & + & 0.520 & 0.721 & 17,345 & $<0.001$ \\
\hline
\end{tabular}

rous fishes proved to be dependent on piscivores (positive relationship) and negatively dependent on omnivores.

Table 6 shows the relationships between macrozooplankton groups and fish trophic guilds. Both copepods and cladocerans had positive relationships of dependence with iliophagous fish biomasses.

The abundance of cladocerans and copepods positively interfere in the concentration of chlorophyll-a, that is, the more abundant are these groups are, the greater the concentration of chlorophyll-a will be. Observing the dependence of the chlorophyll-a in relation to the previous level, it is possible to see that the total phosphorus positively affects the concentration of chlorophyll-a (Table 6).

\subsection{Analysis of Trophic Interactions in the Itaipu Reservoir: Indirect Effects}

Table 6 presents the indirect relationships between chlorophyll-a and fish trophic guilds in the reservoir. The groups of fish that had an influence on chlorophyll-a concentrations were: omnivores and insectivores (negative relationship), and detritivores and iliophagous (positive relationship).

Table 6 presents the results of indirect interactions between the concentration of total phosphorus and groups of fishes. Insectivores and herbivores were the groups of fishes that showed negative interference on the concentrations of total phosphorus.

Table 6 shows the results of indirect interactions be- 
tween the cyanobacteria biomass and groups of fishes. Omnivores, detritivores and insectivores showed negative interference on the abundance of cyanobacteria, while zooplanktivores had a positive relationship.

Table 6 shows the positive dependence between chlorophyll-a and cyanobacteria, indicating that the increased concentration of cyanobacteria favors increased chlorophyll-a concentration.

\subsection{Analysis of the Relationship between Cyanobacteria and Total Phosphorus and Fishes in the Itaipu Reservoir}

The analysis of Table 7 shows that the cyanobacteria were correlated with limnological variables, to reveal which of them had relationships with a dependent variable. This analysis indicated that the density of cyanobacteria had significant positive dependence on chlorophyll-a, water transparency, turbidity, suspended solids and TKN. Only the concentration of suspended solids showed negative interference on them. The multiple regression model explained $33 \%$ of the variability of cyanobacteria $\left(\mathrm{R}=0.571, \mathrm{R}^{2}=0.326, \mathrm{~F}=27,334, \mathrm{~N}=288\right.$, $\mathrm{P}=0.05)$, as expressed by:

$$
\begin{aligned}
\ln \text { cyanobacteria }= & 0.700+(1.536 * \ln \text { chlorophyl }) \\
& +(1.518 * \ln \text { Secchi }) \\
& +(0.417 * \ln \text { turbidity }) \\
& -(0.501 * \ln \text { suspended solids }) \\
& +(3.420 * \ln \mathrm{TKN})
\end{aligned}
$$

The biomass of cyanobacteria was correlated with total $\mathrm{P}$ and omnivores biomass. Phosphorus showed a positive relationship, favoring the development of cyanobacteria and a negative relationship regarding omnivores (cyanobacteria control). The results were $\mathrm{R}=0.872, \mathrm{R}^{2}=0.760$, $\mathrm{P}=<0.001 \mathrm{~F}=18.998, \mathrm{~N}=15, \mathrm{P}=0.05$ (Table 8). The model generated from this analysis was:

$$
\begin{aligned}
\text { lncyanobacteria }= & 17.622+(45.331 * \ln \text { total } \mathrm{P}) \\
& -(2.883 * \text { lnomnivores })
\end{aligned}
$$

Cyanobacteria were also correlated to the concentration of total phosphorus and to detritivorous fishes. Cyanobacteria also developed when there was an increase in Ptotal and showed a negative relationship with detritivores (Table 8). These results indicate that the limiting nutrient for the development of these algae is Ptotal and that the fishes also play a critically important role in this environment. These results can be observed in linear regression analyses that were performed in studies of trophic level relationships (a posteriori).

The multiple regression model explained $78 \%$ of the variability of chlorophyll-a $\left(\mathrm{R}=0.887, \mathrm{R}^{2}=0.786, \mathrm{P}=\right.$ $0.001, \mathrm{~F}=22.025, \mathrm{~N}=15$ ) and this can be expressed by the model:

$$
\begin{aligned}
\text { Incyanobacteria }= & 7.320+(48.976 * \ln \text { total } P) \\
& -(1.097 * \ln \text { detritivores })
\end{aligned}
$$

\subsection{Inference of Fish Yield}

Figure 7 depicts the regression between the capture and

Table 7. Summary of results of multiple regression analysis assessing the effect of chlorophyll, water transparency, turbidity, total suspended solids variables and TKN on the densities of cyanobacteria in the Itaipu Reservoir.

\begin{tabular}{cccccc}
\hline & Coefficient & Std. Error & T & P & VIF \\
\hline Constant & 0.700 & 0.408 & 1.718 & 0.087 & 1.057 \\
Chlorophyll-a & 1.536 & 0.160 & 9.611 & $<0.001$ & 1.567 \\
Transparency & 1.518 & 0.613 & 2.475 & 0.014 & 1.450 \\
Turbidity & 0.417 & 0.190 & 2.197 & 0.029 & 1.554 \\
Suspended Solids & -0.501 & 0.239 & -2.098 & 0.037 & 1.091 \\
\hline TKN & 3.420 & 1.047 & 3.266 & 0.001 & \\
\hline
\end{tabular}

Table 8. Summary of results of multiple regression analysis assessing the effect of total phosphorous and detritivores variables on concentrations of cyanobacteria in the Itaipu Reservoir.

\begin{tabular}{cccccc}
\hline & Coefficient & Std. Error & T & P & VIF \\
\hline Constant & 7.320 & 0.713 & 10.268 & $<0.001$ & \\
Total phosphorous & 48.976 & 18.973 & 2.581 & 0.024 & 1.007 \\
Detritivores & -1.097 & 0.174 & -6.309 & $<0.001$ & 1.007 \\
\hline
\end{tabular}




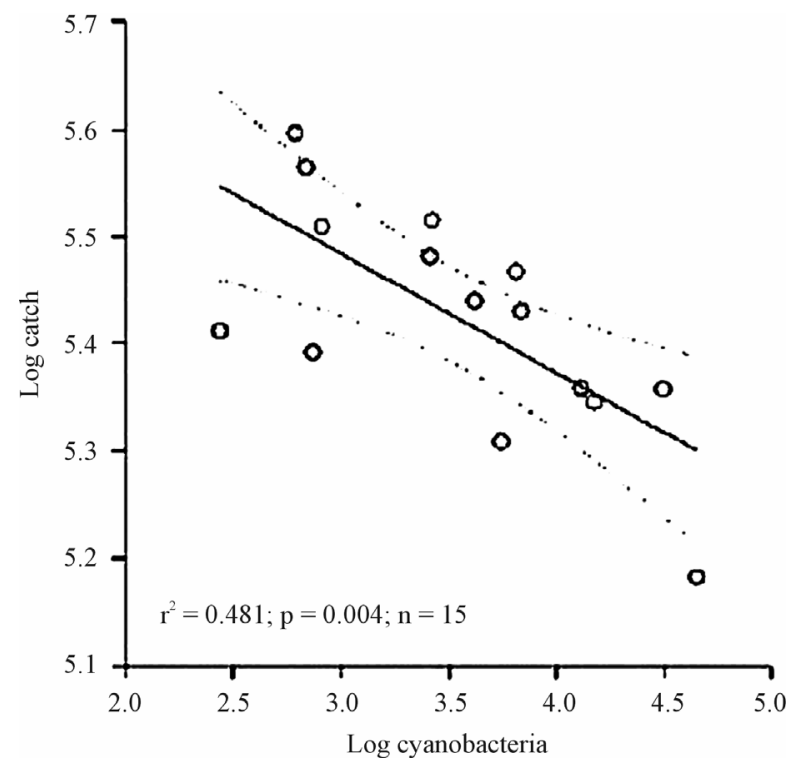

Figure 7. Regression analysis between cyanobacteria log and capture log in the Itaipu Reservoir for the period from 2000 to 2004.

the logarithm values of cyanobacteria densities. This relationship proved to be negative, indicating depletion of capture when there was an increase in cyanobacteria. The values of the correlation coefficient explain $47 \%$ of the model at 0.05 significance.

The results of the inference of fish production by means of empirical models for the Itaipu Reservoir are shown in Figure 8. According to this inference, the reservoir had an average fishing yield of $8.1 \mathrm{~kg} / \mathrm{ha} /$ year. The transition and riverine zones had the highest mean productivity $(8.2 \mathrm{~kg} / \mathrm{ha} / \mathrm{year})$, while the lacustrine zone obtained an average yield of $8.1 \mathrm{~kg} / \mathrm{ha} /$ year.

\section{Discussion}

\subsection{Limnology of the Itaipu Reservoir}

Limnological variables are of crucial importance to cha- racterize the zones of a reservoir. According to its longitudinal variation, to the sedimentation of allochthonous and autochthonous material in the environment, a reservoir has essentially three main zones: the riverine region, the transition region and the lacustrine region [63]. These regions have a horizontal distribution, with their own dynamics, being influenced by inflowing water from rivers and by the outflow of water through spillways and turbines.

The Itaipu Reservoir shows strong relations between the riverine, transitional and lacustrine zones. According to [64] these relationships suggest that the seasonal variability can be explained by the hydrodynamic process, especially because of the discharges that the Rio Paraná suffers, causing an irregular dynamics of the limnological variables.

The analyses of this study indicated that the Itaipu Reservoir showed horizontal spatial heterogeneity for some limnological and biological variables. When one examines the topographical map of the valley of the Itaipu Lake [65], it is evident that the topography of the transition zone favors increased water inflow [66], explaining a major input of allochthonous material to the reservoir.

[67] evaluated the transportation of nutrients and suspended material in different parts of the Paranapanema River and its tributaries. The results explain the importance of the hydrological cycle, in particular precipitation, and of the lateral and longitudinal dimensions.

The use and occupation of land is an extremely important factor in reservoir studies. Activities such as monoculture and large areas of pasture may increase concentrations of nutrients in the aquatic ecosystem. On the banks of the reservoir, on the Brazilian side, there are large areas that contribute to the acceleration of eutrophication of the reservoir (diffuse pollution), while on the Paraguayan side there are still large areas of forests along the reservoir.

A study in the São Simão Reservoir (MG) showed that

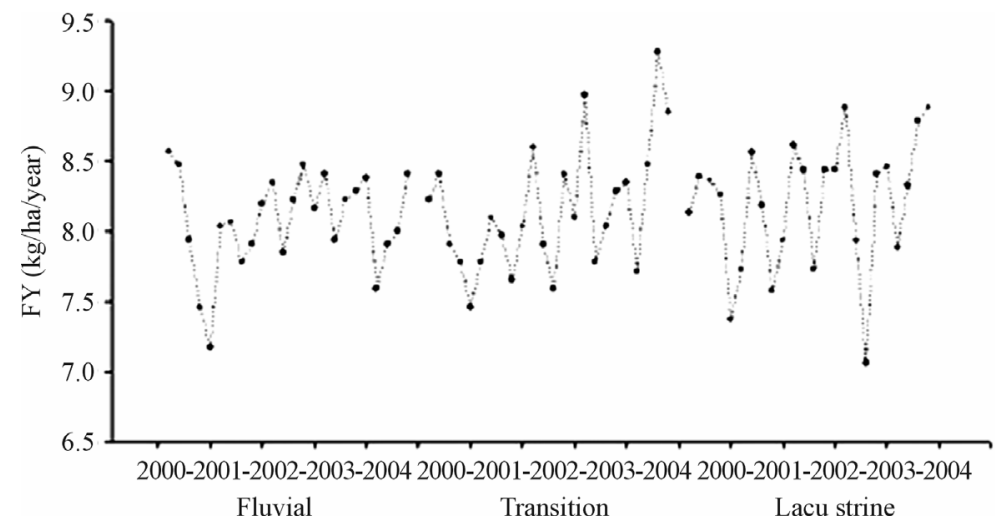

Figure 8. Estimates of fishing yield (FY) in $\mathrm{kg} / \mathrm{ha} / \mathrm{year}$ according to the zones of the Itaipu Reservoir, for the period from 1999 to 2004. 
the highest concentrations of nutrients and solids flowing into the reservoir were found in rivers where there was agriculture and livestock [68]. The same effect can be observed in cascade reservoirs of the Paranapanema River [69].

Temperature is one of the most important variables a) in the distribution and physiology of aquatic organisms, what may cause altercations in the dynamics of nutrients in the water column [70] and b) in studies of the food web and biomanipulation in lakes and reservoirs, influencing the metabolic rates of fish [71]. The ammonia excretion rates increase with the increase of this variable [72] and phosphorus cycling by fish is accelerated [73, 74]. In the Itaipu Reservoir water temperature showed a distinct pattern of seasonal variation, with the highest temperatures recorded between November and March and the lowest from May to August. The highest temperature was found in the lacustrine zone $\left(30.4^{\circ} \mathrm{C}\right)$. These data are consistent with those described by [50] and [75], and in reservoirs located in the Serra do Mar, state of Paraná [76].

Water transparency has a strong influence on the trophic aquatic environments, and penetration of light determines the development of phytoplanktonic organisms and therefore environmental enrichment [70,77,78]. In addition to the input of allochthonous material, which is transported and sedimented in water, contributing to the reduction of water transparency, high fish biomasses can also reduce water transparency $[4,27,79]$ due to increased nutrients owing to the excretions of fishes $[20,80]$.

In the Itaipu Reservoir the lowest water transparencies were recorded in the riverine zone due to the transportation of particles and sedimentation rates, which are directly associated with the inflow of water courses. The data analysis of suspended solids indicates that, as this variable diminishes, water transparency increases, as noted by $[49,75]$.

The values of water transparency were related with some limnological variables and the results indicate that the chlorophyll-a, turbidity, suspended solids and total phosphorus variables influenced negatively water transparency. This can be explained by the fact that when the independent variables increase in value, the dependent variable increases, interfering directly in the amount of light in the system. The variables ammonia nitrogen and TKN showed a positive effect, contributing to the increase in water transparency. This occurred because the forms of nutrients are related with the increase of primary productivity, indicating casual relations, so that these variables have their effects limited by the availability of light into the water environment.

The concentration of suspended solids in the water, besides the water cycle and turbidity, is also one of the most important limiting factors to primary production in environments that present high values of this variable, influencing the photosynthetic behavior and causing changes in the ecology of the ecosystem [81]. It is important to note that climatic factors such as rainfall play an important role especially with regard to the water transparency variable. The results of the analyses comparing rainfall and water transparency demonstrate the negative effect, what means that this variable is of great importance to measure the productivity of aquatic environments. [81] emphasize that the discharge of solids in the Paraná River was at around 30 million tons per year, of which only $10 \%$ refer to bed material load. The suspended load varies according to the flood peaks (precipitation).

The turbidity of water the measurement that expresses the loss of light penetration into the aquatic environment, as it is a result of all organic and inorganic material that is in suspension in water in the form of particles [82]. In the Itaipu Reservoir this variable showed very similar values among the riverine, transition and lacustrine zones, although it presented declining average values in the upstream-downstream direction, confirming the results of [75]. The highest values of turbidity can be explained by occasional periods of rain just before and during the collection of data, as observed by [83] in Salto Grande reservoir (Americana, SP) and by [68] in São Simão Reservoir (MG). This variable is very important because many species of predator fishes have a visual active persecution feeding tactics [84], promoting the re-suspension of organic and inorganic materials as they move around to catch food [85]. This variable is directly related to the decrease in water flow, resulting in a lower input of suspended materials in the water.

According to [70], the $\mathrm{pH}$ represents the ionic balance in the aquatic environment, interfering directly with the conditions of neutrality of water and environmental buffering capacity (alkalinity). The increase of this variable may be related to changes in the values of alkalinity in aquatic ecosystems, explaining the inverse relationships of the alkalinity values found with regard to $\mathrm{pH}$. The Itaipu Reservoir, in general, presented an alkaline $\mathrm{pH}$ with slight tendency to neutrality. These results are in consonance with those by [48]. The fact that the transition zone presents higher $\mathrm{pH}$ values may be related to higher photosynthetic activity (cyanobacteria) in this region [86]. [23], in an experimental study, found that concentrations of $\mathrm{pH}$ and $\mathrm{CO}_{2}$ are variables that help to determine the cyanobacteria populations.

Electrical conductivity is the resistivity ability to transmit electricity in the water body, reflecting indirectly the level of dissolved solids in water. In some studies the increase in conductivity was accompanied by the increase of cyanobacteria [87]. In the Itaipu Reservoir, although quite discrete, the highest conductivity was re- 
corded in the transition zone. The exclusive presence of tilapia (Oreochromis niloticus and Tilapia rendalli) when compared to treatments without the presence of fishes in studies by $[88,89]$, showed an increase in the values of electrical conductivity as a result. The ion concentrations in the lacustrine area can be explained by the higher biomass of piscivore species, justified by the control of omnivore biomass [90].

The dissolved oxygen in the aquatic ecosystem is a limiting factor for both nutrient cycling and for primary productivity [52]. In this study, we observed a pattern in their distribution with regard to seasonality during the months the data were collected, confirming the results reported by [50], in which the lowest dissolved oxygen concentrations were found in summer (January to March) and the highest during the rainy season (June to August). For this work, the highest amount of dissolved oxygen in the transition zone may be associated with the great development of algae, especially cyanobacteria. The month of March, for all years, presented the lowest concentration of this gas, as it is strongly affected by water temperature (in warmer months there is loss of oxygen into the atmosphere and increased metabolism of the environment).

In a study by [91] in reservoirs in the middle and lower Tietê River (SP) high concentrations of dissolved oxygen were found in the water surface. The author stresses that these findings may be related to the rainy months and other studies also emphasize the effect of rainfall in the distribution pattern of dissolved oxygen [92].

The BOD variable represents the amount of oxygen required to oxidize organic matter by microbial decomposition. The increase in the values of this variable represents an increase of organic or punctual pollution [93]. The transition zone showed the highest mean values due to swine breeding activity in that area of the watershed (BENASSI, S.F., personal communication, 2006).

The COD variable represents the amount of oxygen required to oxidize organic matter by means of chemical agents. The increases in the DQO values in water bodies are indicative of industrial pollution [93]. As with the BOD, COD showed a higher average concentration in the transition zone $(7.5 \mathrm{mg} / \mathrm{L})$, which can also be associated with the input of materials into the reservoir.

The nitrogen and phosphorus are the main nutrients for aquatic environment primary producers [70] and the mean increase of nutrients means changes in the abundance of fishes, in what regards composition and biomass in temperate lakes [94]. The fish biomass and their density per unit area of the lake increase with increasing concentration of total phosphorus [95,43], so that the concentration of predatory fishes is reduced [96,25].

Among the nitrogen forms mostly consumed by the communities of aquatic ecosystems are ammonia nitro- gen, nitrate and nitrite. Nitrite is the intermediate state between ammonia and nitrate, during the nitrification process, and is not very much available in the environment and used by primary producers. Nitrite is a very complex variable, because it is converted into ammonia or nitrate and unlikely to accumulate in the system, what explains the lack of relationship with chlorophyll-a. Their low concentrations may also indicate a high oxygen environment [70].

The nitrate concentrations in the reservoir had a horizontal longitudinal distribution. The results were similar to those found previously in the Itaipu Reservoir [50], but in lower concentrations.

Ammonia nitrogen is the least found nitrogen form and one of the most frequently used by primary producers. This is because the ammonium ion can be used as a nitrogen source during protein synthesis by primary producers. This may happen as ammonia is one of the main forms of nitrogen excreted by fishes [97]. In the Itaipu Reservoir the average concentration of this variable was $0.03 \mathrm{mg} / \mathrm{L}$, confirming the results of [53], with average values of $0.033 \mathrm{mg} / \mathrm{L}$.

The total Kjeldahl nitrogen (TKN) is the sum of forms of organic and ammonia nitrogen, which are extremely important for biological activity. In the Itaipu Reservoir this form of nutrient was the one which presented the best relationship with the chlorophyll-a concentrations, and positive relationship with water transparency, as evidenced by multiple regression analysis. The concentrations of total Kjeldahl nitrogen in the reservoir had horizontal distribution similar to that found by $[50,75]$, with the transition zone having higher concentrations of this nutrient. This was the variable that best correlated with the chlorophyll-a variable, corroborating the results found by [98], thus demonstrating the assimilation of this source of nitrogen by phytoplankton $[70,99]$. The relationship between the nitrogen forms of chlorophyll was also observed by $[100,101]$, who found a direct relationship between the reductions in nitrate and ammonia concentrations and increase in concentrations of chlorophyll-a in experiments in ponds with known fish biomasses.

Phosphorus is found in the aquatic environment in the same way that nitrogen is (organic and inorganic/in particles and dissolved) and together they are the most important nutrients for primary production in aquatic ecosystems. The lowest average concentration in the lacustrine zone of Itaipu Reservoir can be explained by sedimentation rates throughout the watercourse. It is important to stress that the P.total in this zone may have more effect on productivity (chlorophyll-a) owing to the luminosity factor [102]. This explains why the phosphorus had no significant relationship when related to chlorophyll-a and water transparency in the multiple regression 
analysis of the Itaipu Reservoir.

Comparing the total phosphorus concentrations with the results $[50,75]$, it is possible to observe that the reservoir presented a seasonal longitudinal distribution pattern that is similar in both studies. The concentrations of this nutrient were similar in both studied zones [50] and this showed that the constant reduced concentrations of total phosphorus is an important implication for the absence of eutrophication in the Itaipu Reservoir. [63] point out that inhibition of the eutrophication process can be associated with the retention of this nutrient in cascade systems reservoirs located upstream of the Itaipu Reservoir, and studies conducted by [69] show a decrease of phosphorus in cascade systems reservoirs. Furthermore, [50] point out that large sources that carry phosphorus into the reservoir are limited by the tributaries and the floodplain.

The impact of fish that feed on sediment detritus, making available large concentrations of phosphorus for phytoplankton has been studied by several authors [20, $74,80,103]$. In Paranoá Lake this impact was observed in the stock of tilapia due to their omnivorous feeding habits, more than $50 \%$ of their stomach contents consisted of sediment in the study by [104], what through excretion is released into the water column, increasing the concentration of phosphorus [105].

The primary productivity, which can be expressed indirectly by the concentration of chlorophyll, is controlled by the action of light and nutrient factors [106], considered fundamental to the development of phytoplankton productivity in freshwater ecosystems.

The horizontal distribution of chlorophyll-a concentrations in the Itaipu Reservoir showed significant relationships with almost all forms of nutrients. The multiple regression analysis indicates that the nitrate and ammonia nitrogen negatively affect primary productivity, while the total Kjeldahl nitrogen and total phosphorus positively affected the primary productivity. These results corroborate those by [107] in six reservoirs in the state of Paraná, where they found similar effects of nutrients on chlorophyll-a and verified the same pattern of distribution.

The phytoplankton community of a reservoir is maintained by continuous input of nutrients (inflows) and by the nutrients recycled by zooplankton and fishes. A way commonly used to quantify the amount of algae in a specific reservoir is by determining the concentrations of chlorophyll-a [1].

The pattern of longitudinal distribution of chlorophyll-a in the reservoir was constant for the riverine and lacustrine zones, where the average concentrations found were similar. On the other hand, the transition zone, whose highest concentrations of chlorophyll were associated with higher nutrient concentrations, showed a distribution related to the seasonality of rainfall. Studies by
[75] corroborate the results of the present study. The highest concentrations of chlorophyll-a in the Itaipu Reservoir, in the transition zone, are explained by higher concentrations of total Kjeldahl nitrogen, total phosphorrus and nitrate, and, apparently, these correspond to the forms of nutrients that were influential in increasing concentrations of chlorophyll-a. [107] commented that the prevalence of high concentrations of chlorophyll-a in the intermediate zones (transition) are due to the ideal relationship between light and phosphorus, most found in these regions, increasing primary productivity. The authors emphasize that this pattern in the distribution of chlorophyll-a is not always found and this is because other factors (such as residence time, reservoir size, morphometry, etc.) influence the metabolism of primary productivity.

It is important to stress that the impact of diffuse pollution (agricultural) and punctual pollution may be increasing nutrient levels in the Itaipu Reservoir, as it can be seen in satellite images of the region where the Itaipu Reservoir is located [65]. Another aspect to be analyzed with regard to the transition zone is that, besides a steeper topography, a large swine farming activity is practiced in the São Francisco Verdadeiro e Falso River micro basins, producing pollution due to an increase in nutrients caused by lack of waste treatment of these farms (BENASSI, S.F., personal communication). Most of these properties are located near the banks of tributaries of the reservoir, explaining the increase of nutrient concentrations, and consequent higher occurrence of cyanobacteria in this region.

\subsection{Trophic State Index (TSI)}

The Trophic State Index is intended to classify water bodies according to nutrient enrichment and is obtained through statistical analysis of linear regression models [59]. Water transparency many times does not show values that represent the trophic status of the environment, especially for the oligotrophic limit value. For this reason, we started to use the weighted average of the indices calculated by assigning a lower weight ratio to water transparency (Secchi disk reading), without having to remove it from the calculation of the TSI average.

The results obtained show that the transition zone has a higher trophic status than the other zones, what can be related to the higher nutrient input (diffuse pollution), as discussed above, or by the ratio of optimal light with the nutrient concentrations. The mean values of TSI indicate a slight improvement of the trophic state of water, according to spatial and temporal patterns. The values found for lacustrine zones indicate that these regions are oligotrophic. On the other hand, the riverine and transition zones showed higher values, reaching concentrations that indicate a mesotrophic level with some eutrophic 
values in the transition zone. Nevertheless, the average value for the entire reservoir, disconsidering the zone divisions, indicated that its waters can be classified as mesotrophic, corroborating studies by [75]. These changes in trophic status among different regions were also found by $[83,91]$, in which precipitation and diffuse pollution were the factors that best explained the changes of the trophic status.

Another important factor to consider is the cascade system upstream of the Itaipu Reservoir, present in the Tietê, Grande and Paranapanema rivers, which supplies waters to the Paraná River, forming the reservoir. This factor may have a great influence, as the concentrations of nutrients and particulate matter undergo a lowering effect through the successive reservoirs in cascade systems $[69,75]$.

\subsection{Analysis of Longitudinal Distribution of Biological Communities}

The responses of the communities in reservoirs under manipulated conditions or not, are incomplete, as they are altered or destroyed before complete interactions. The instability of the formation of a new environment makes communities unstable due to anthropogenic activities and damming [49]. The process of spatial and temporal succession of communities in reservoirs depends on the speed of filling, withdrawal of vegetation or not, on the establishment of an extensive coastal zone which increases the substrate and the processes of colonization of the basin [107].

According to [63] the seasonal cycle of phytoplankton in reservoirs is due in large part to hydrodynamic changes. The pulses produce sudden changes in the system, with rapid discharges in the surface, producing impacts owing to the input of material in suspension, nutrient availability and solar radiation (which causes changes in the specific composition of the phytoplankton), as well as the frequency of turbulence caused by the action of winds (which affects the spatial distribution, horizontal and vertical of phytoplankton in reservoirs). The authors emphasize that the pattern of horizontal distribution determines the distribution characteristics of phytoplankton, resulting, in many cases, in algal blooms due to the accumulation produced by the horizontal surface currents.

The relationship between the composition and distribution of phytoplankton and the physicochemical regimes are complex and the interaction can be understood only with long-term studies [63].

The variation in density, according to the main groups, shows a distribution pattern among the zones of the reservoir, in which we observed the dominance of cyanobacteria $(76 \%)$ and that the remaining groups of algae were less abundant. These results corroborate those by [68], who obtained cyanobacteria abundances of values of $11.000 \mathrm{ind} . / \mathrm{ml}$, and [75], in the Itaipu Reservoir, with the highest densities of cyanobacteria Mycrocystis kutzing. Only in the transition zone cyanobacteria blooms were recorded, a fact that can be explained by higher nutrient availability in the rainy season and by the $\mathrm{pH}$ values [23]. One aspect that should be considered is the type of data collection, with water samples taken only from the surface, the area of greatest development of cyanobacteria [63].

The low densities of phytoplankton groups studied can be justified by the low average concentrations of nutrients. According to [108], all phytoplankton species are likely to keep growing as long as nutrients are available, and faster growth species are selected in environments with favorable nutritional conditions.

The results of multiple regression analyses indicate that the independent variables water transparency, turbidity, and TKN showed a positive effect on the development of cyanobacteria in the Itaipu Reservoir, and the variable suspended solids influenced negatively in their development. The generated model can estimate the biomass of cyanobacteria from the independent variables mentioned above.

When cyanobacteria were related to total phosphorus and fishes, the results indicated that the limiting nutrient for the development of these algae is total phosphorus, and the fishes also play an extremely important role in this environment.

The proportion between the different groups that make up the zooplankton community (rotifers, copepods and cladocerans) is considered a way to use this community as an indicator of the trophic conditions of the environment, and the dominance of rotifers is often associated with increased eutrophication [109].

In the Itaipu Reservoir the most dominant group was Copepoda, with the highest densities in the whole system (57.97\%). Studies in reservoirs of Paraná indicate the same dominance of copepods [110] and in the Tucuruí Reservoir, [111] observed the same pattern. The highest density of Copepoda as well as of Cladocera, may be associated with a higher trophic level in the zones where the concentration of chlorophyll and cyanobacteria were higher. According [112], higher densities of zooplankton in the transition zone are observed when resource availability and hydrodynamics are interacting to determine abundance patterns.

The greatest abundance of zooplankton was recorded in the transition zone of the Itaipu Reservoir. Studies by [113] in reservoirs of the state of Paraná showed results that corroborate the results of this work. The highest abundance in the transition zone is explained by higher concentrations of chlorophyll-a, due to increased human activity observed in the basins of the San Francisco Verdadeiro e Falso Rivers, located in the transition zone. The 
distribution of small cladocerans may be related to the abundance of cyanobacteria, especially in eutrophic environments [115]. The biochemical properties of cyanobacteria (and some species may be toxic) and the shape and size of colonies prevent an overexploitation of this resource by zooplankton, keeping the abundances of colonies stable [115].

The second most abundant group was the rotifers. Although eutrophic and hyper eutrophic environments favor the dominance of rotifers, in most aquatic environments of Brazil rotifers are often dominant, regardless of trophic status, both in density and in number of species [116]. The non-dominance of rotifers in the Itaipu Reservoir $(32 \%)$ is consistent with the results for oligotrophic and mesotrophic lakes in the United States [116], in which rotifers represent $20 \%$ to $37 \%$.

Regarding the distribution of the longitudinal axis of the reservoir, the highest density of rotifers was found in the riverine zone and in the remaining zones there was a dominance of copepods. Studies in the reservoir of the Corumbá River [113] show that the community structure was altered after the construction of the dam, when the densities of cladocerans and copepods showed greater development. Other authors relate the trophic status in the community structure of zooplankton [109,114].

The study of the determination of the time-space variation of fish communities and the way in which these stocks are removed from the environment are used to rationalize fishery management [117]. According to [118] fish populations have effects of fundamental importance in trophic cascades, with direct influence on biomass and productivity of other trophic levels.

The results of the variation of the trophic structure of the fishes show that the group of omnivores was most abundant in the reservoir, followed by piscivores. These two groups accounted for $77.7 \%$ of the total biomass. The riverine zone showed higher occurrence of omnivores and detritivores. In the transition and lacustrine zones omnivores and piscivores were more abundant. [48] also found eight trophic groups in the Itaipu reservoir in the period between 1983 and 1986. Then, the piscivores were dominant $(25.6 \%)$, followed by iliophagous $(15.6 \%)$, omnivores $(12.5 \%)$, insectivores $(9.4 \%)$, herbivores $(3.4 \%)$, planktivores $(1.6 \%)$ lepidofages-insectivores $(1.6 \%)$ and others $(9.4 \%)$. [50] in a six-year study (1983 to 1989) in the Itaipu Reservoir, found similar results, with higher occurrences of omnivores and piscivores. [55] found greater biomass of hake Cynoscion spp. (piscivores), detritivores and omnivores in the Itaipu Reservoir. The differences between the trophic guilds of fishes in the present study compared to those of [55], can be explained by differences in sampling methodology, as these authors used only gillnets in their studies. The results presented here are derived from landings of com- mercial fishing, where fish biomasses are best represented by the fact that fishermen pursue this activity with greater frequency. The monitoring of professional fisheries in the Itaipu reservoir began in 1985 and persists to this day, and it is of great importance for understanding the dynamics of fishes in the reservoir.

[52] characterized the structure of trophic guilds of fishes of the Paraná River, in which piscivores were more abundant and diverse. The authors emphasize that the dynamics of the environment is related to the diversity of species in trophic categories, as evidenced by the structure of the diversity of its abiotic component and by the biotic interrelationships governed by the hydrological cycle.

As the Itaipu Reservoir is an artificial damming of the Paraná River, it is expected that the structure of the fish community should have a strong influence of the hydrological regime of the river. The study mentioned above found greatest abundance of piscivores and iliophagous, both favored by the effect of the flood pulse, developing ideal areas that favor the increase of these stocks (reproduction and feeding). This effect may explain the large biomass of omnivores and piscivores recorded in this study, in which the riverine and transition zones showed large biomasses of omnivores, and piscivores were more dominant in the lacustrine zone.

\subsection{Trophic Relationships (Top-Down and Bottom-Up) in the Itaipu Reservoir: Direct and Indirect Effects}

The theory of trophic cascade in lakes and reservoirs is based on the fact that each trophic level of the food chain is inversely and directly related with trophic levels above or below, following two principles: the loss of energy between a trophic level and a higher one, and the disturbance in a trophic level brings consequences to the remaining trophic levels. The studies that have tested and confirmed this hypothesis in temperate lakes and reservoirs are numerous [2,4,5,7,8,15,23-25,29-31,96,119126], unlike what happens in tropical lakes, where studies of trophic cascades are scarce $[46,127,128,32,47$, 129].

The top-down effects in temperate environments are explained by $[15,18]$, where relationships between trophic levels suffer negative effect of the presence of piscivores on the lower levels.

[32] investigated the effects of trophic cascades in dams of Pernambuco. The relationships that are well explained in temperate climate lakes and reservoirs were not so evident in tropical environments. The authors suggest that the state of the trophic guilds of fishes plays the main role in food webs in reservoirs of northeastern Brazil, where indirect effects between chlorophyll concentration and the densities of omnivores have a positive 
relationship, indicating that omnivores somehow contribute with some kind of pressure towards the development of chlorophyll-a. According [129], this is because the wealth of fish species is often higher in tropical and subtropical lakes. South America and Africa have a very rich freshwater fish fauna and many species of fishes show a partially overlapping niche, increasing the control of prey [18]. This effect was also observed by Stein et al. (1995) in lakes in southern United States.

Fish communities in tropical and subtropical lakes are often dominated by omnivores, which have great feeding plasticity, consuming zooplankton, phytoplankton, periphyton, benthic macro invertebrates and debris. According to [32], the piscivores are represented in few species and in small biomass and a greater biomass of small carnivores and omnivores generally governs the dynamics of the trophic chain.

Some species of omnivores are not controlled by the availability of food resources (zooplankton) and not even by the pressure of predation as they are bigger in size than their potential predators. The top-down control by piscivorous fishes is therefore weaker in subtropical/ tropical lakes than in temperate lakes.

[11] notes that in most previous studies involving the impact of planktivorous fish the feeding behavior of the species was not determined and, consequently, the mechanisms that determine the feeding selectivity of the fishes and the use of resources were not well understood. The author explains that fishes have great ability to change their pattern of feeding selectivity, and classifies fishes according to the way they feed: visual particulate, filtration, pumping and filtration drag. In the case of the first two, several factors influence the success of predation, as prey size and light intensity, and species of young fish that feed by visual mode particles may switch to filter-feeding by pumping when they become adults. [12] demonstrated this effect in laboratory experiments with a cichlid species, the Geophagus brasiliensis. [137] tested the feeding selectivity for the same species in experiments in mesocosms in situ in the Lobo-Broa Reservoir (SP). The authors found that the biomass of Daphnia sp decreased in treated fish, showing the pressure for food selectivity, confirming the laboratory studies by [12].

In systems where there are high fish densities, there may be loss of weight and animal death [15]. The presence of a predator provides stability to the system, since, with predation, there is a reduction of the stock of prey, thus avoiding the lack and competition for food by the forage species. Paiva et al. (1994) conducted a study where the number of predator species interfered with the trophic dynamics in reservoirs of northeastern Brazil. They noted that the reservoirs in which there were two species of predators fish catching was high, while in reservoirs with less than two species of predators, competi- tion among prey probably contributed to the decrease in catch.

Several authors suggest that the community structure and biomass of fresh water are regulated by predators $[2,4,23,24]$. It can be said that an increase in piscivore biomass is associated to reduction of planktivore biomass, increase of large zooplankton biomass and reduction of phytoplankton $[15,25,29]$. The interactions established by predation can promote the reduction of the planktivore biomass and these, associated with increased biomass of large zooplankton and the increase of algae consumers (grazing), reduce the phytoplankton biomass. Several authors [23] have noted that predators are important to zooplankton alterations.

According to the trophic cascade hypothesis, the increase in piscivore (carnivore) biomass in a lake or reservoir causes [23] the planktivorous fish biomass to decrease, increasing the zooplankton biomass and reducing phytoplanktonic biomass $[4,24]$.

[32] point out that top-down effects in tropical environments are more complex than in temperate environments, as there are no species that are essentially zooplanktivorous but omnivores (such as tilapia), and the piscivores give way to general macro carnivores. The chlorophyll-a concentration increases with the omnivorous fish biomass and decreases with macro carnivore biomass. However, in this work, the chlorophyll-a concentration was not related to total fish biomass and to the macrozooplankton biomass. Interactions between fishes and chlorophyll concentration and between fish and zooplankton biomass were inversely related to the trophic state. The fish-phytoplankton regulation caused by complex omnivore interactions is present in the feeding behavior of various populations of consumers.

The results show that the Itaipu Reservoir presented top-down and bottom-up relationships, supporting the findings by [47] in experiments in a lake in Bolivia, with direct and indirect effects on the trophic cascade. The top-down effect was found only in the first trophic level and the biomass of piscivores exercised a control over omnivores and detritivores, and had no predatory effect on the benthivore and zooplanktivore biomasses, whose biomasses actually increased. This suggests that the piscivores may have an effect on the water quality of the reservoir, not positively, but negatively, since the indirect relations between the guilds consumed by predators have shown to have a controlling effect on both chlorophyll-a and cyanobacteria. The control effect of piscivores was also reported by [139] on 31 reservoirs of the state of Paraná.

The effect of omnivores on the other trophic groups of fishes were also evaluated, since this group is composed largely of big fish (Pimelodus sp and Pterodoras granulosus, for example). This analysis indicates that the in- 
crease in omnivore biomass caused depletion of benthivore and detritivore biomass, contrary to what happened with the zooplanktivore, which had their biomass increased.

An important relationship studied was the one between detritivores and primary production in the reservoir. Although the results indicate that this group suffers a strong predation pressure by piscivores and omnivores, detritivores promote control over chlorophyll-a and cyanobacteria.

When the omnivore filter-feeders dominate the planktivorous fishes, the hypothesis "fishes versus trophic state of the lake" can no longer be valid because the growth stimulation by omnivores is intensified by the increased load of nutrients [19]. The systems dominated by omnivores show weak trophic links, due to a combination of weakened mechanisms. Consequently, they are difficult to predict with the trophic cascades hypothesis. Among the mechanisms involved, [32] comment on the "intraguild predation" (IGP), which applies to omnivores that feed on herbivorous zooplankton and on their phytoplanktonic food and also ontogenetic omnivory (the same mechanism that occurs during the fish ontogeny from the juvenile phase to the adult).

The lack of zooplanktivore predation effect demonstrated in the statistical analysis also indicates damage to water quality, with positive effect related to the cyanobacteria. Studies by [138] emphasize the great adaptability that zooplanktivorous species have owing to their gill system, as their gills are large, long, thin and numerous. For instance, the filtration mechanism of Hypophthalmus marginatus is of the passive filter kind that consists in swimming with an open mouth and with extended operculum, and their diet is composed primarily of zooplankton. These results demonstrate the importance of omnivore and detritivore chains in tropical and subtropical aquatic environments. These results corroborate the work of $[18,32]$, which emphasize the effect of omnivores and the detritivore chains in these environments.

The only guild of fishes that showed some relationship with the macrozooplankton was the one composed by iliophagous, and the relations were positive and not negative as they occur in temperate ecosystems [15]. These results suggest that the increase in iliophagous biomass causes an increase in herbivorous zooplankton communities, indicating that the pressure of fishes does not affect the zooplankton community, which is capable of consuming the phytoplankton, what appears to be a bottom-up effect.

The low pressure the fishes cause on zooplankton implies the dominance of small individuals in the zooplankton communities in tropical and subtropical lakes [18]. The omnivorous copepods biomass usually dominates in oligomesotrophic systems, whereas microzoo- plankton prevails in more eutrophic systems. At higher temperatures, the daily fluctuations of the physical or chemical conditions or sudden environmental changes (due to heavy rain, for example) may affect the zooplankton community (increasing the number of protozoa and rotifers), but it has the ability to recover very quickly. The classic control of phytoplankton by macrozooplankton in temperate lakes is not as often seen in tropical lakes $[18,129,47]$. This absence of predation pressure on zooplankton may represent an additional limitation on the difficulty of biomanipulation in tropical and subtropical lakes.

While studying mesocosms [140] found that the predator causes a strong impact on the planktivore community, but the interactions of the trophic levels below these communities did not show a strong effect on the phytoplankton and zooplankton communities. The results described above can explain the increased biomass of the zooplankton community, with regard to the macrozooplankton analyses (cladocerans and copepods), in this study. The results show that there is no predatory pressure of fish on zooplankton. Studies in 31 reservoirs in the state of Paraná showed the same positive relationship between chlorophyll-a and macrozooplankton. According [18], in tropical environments prey are not strictly zooplanktivorous, but omnivorous, having no direct effect on zooplankton community.

The macrozooplankton (cladocerans and copepods) showed a positive relationship with chlorophyll, indicating that the former had no control over the latter. These results corroborate the work by $[114,135]$, held in reservoirs of Paraná, in which positive relationships were also found between zooplankton and chlorophyll-a. This type of relationship is opposite to what is commonly found in temperate lakes and reservoirs $[5,15]$, indicating a bottom-up effect.

The last trophic level examined, confirming the bottom-up effect, was the chlorophyll-nutrient interaction, where increased concentrations of chlorophyll-a were positively related to the concentrations of total phosphorrus. In temperate environments this ratio is positive $[15,5]$, and nutrient concentrations control chlorophyll-a concentrations.

[130] point out that a complicating factor for the functioning of the trophic cascade hypothesis is the assumption that all populations of planktivorous fish are susceptible to increased biomass of piscivores. [16] also shows that the morphological characteristics (such as mouth opening of predators) and prey refuges are factors of extreme importance for the development of the trophic cascade hypothesis.

Indirect relationships indicate that omnivores, insectivores and detritivores control chlorophyll and cyanobac- 
teria. These three groups of fish can be used to control the quality of water in the reservoir, and laboratory and in situ experiments may provide answers for the management of this environment. The iliophagous and zooplanktivorous fish showed positive relations with chlorophylla and cyanobacteria, respectively. These results indicate that both groups of fish somehow stimulated the development of primary productivity. Measures such as the encouraging of catchment of these species in both artisanal and sport fisheries would bring beneficial results in the control of water quality in the reservoir.

Insectivores and herbivores were the only groups of fish that were somehow related to the concentration of total phosphorus. Both showed negative relationships with phosphorus, indicating that an increase of the biomass of these causes a reduction in the total phosphorus concentration. These results imply that management of these species (increase of stock) may have a greater control of total phosphorus in the reservoir.

[74] compared the rate of excretion of phosphorus in zooplanktivorous fish, with estimates of internal and external loads in a eutrophic lake (Lake Finjasjon, Sweden). The experiments were performed in the laboratory using two prey species (one benthic and one pelagic), and the results were extrapolated to the entire lake, using the calculation of consumption of prey by the fish, based on field data on community structure, growth rate of excretion and diet of the fish. The phosphorus rate excreted by the fishes was on average $0.53 \mathrm{mg} \mathrm{P} / \mathrm{m}^{2} / \mathrm{d}$, which had a $110 \%$ increase of external load and $42 \%$ of internal load. Most of the phosphorus released by the fish is recycled within the water column, that is, more than $18 \%$ of phosphorus released in the water comes from the benthic food, thus representing the transportation of phosphorus from the sediment to the water column. Phosphorus excreted by the fishes became available for phytoplankton, suggesting that the nutrient may constitute an important source for algae.

Fishes release phosphorus in the water directly through metabolic processes (excretion) and, indirectly due to their habit of turning the sediment in search of food, making nutrients available in the water column [74,105]. [20] stresses that the importance of fish in maintaining the concentration of phosphorus of the water can be greater than that of allochthonous sources, primarily as a source of nutrients in the pelagic region. [131] point out that the soluble phosphorus is the main form of phosphorus excreted by fish, and [20] demonstrated that tilapia are the fish that have the highest rate of excretion of soluble phosphorus in Lake Paranoá.

While analyzing the relations between one trophic level and another, we observed that the Itaipu Reservoir presents strong evidence of a bottom-up force, whose positive effects can be found throughout the reservoir. Only the analyses of the fish predation effect on fish showed negative relationships, indicating that there is a top-down effect. These results suggest that the Itaipu Reservoir presents both types of effect. While the bottom-up effect was observed in three trophic levels, the top-down effect was found only in one level. The food web is presented in Figure 9 and shows the direct and indirect top-down and bottom-up effects in the Itaipu Reservoir.

It is important to stress that the Itaipu Reservoir, lo-

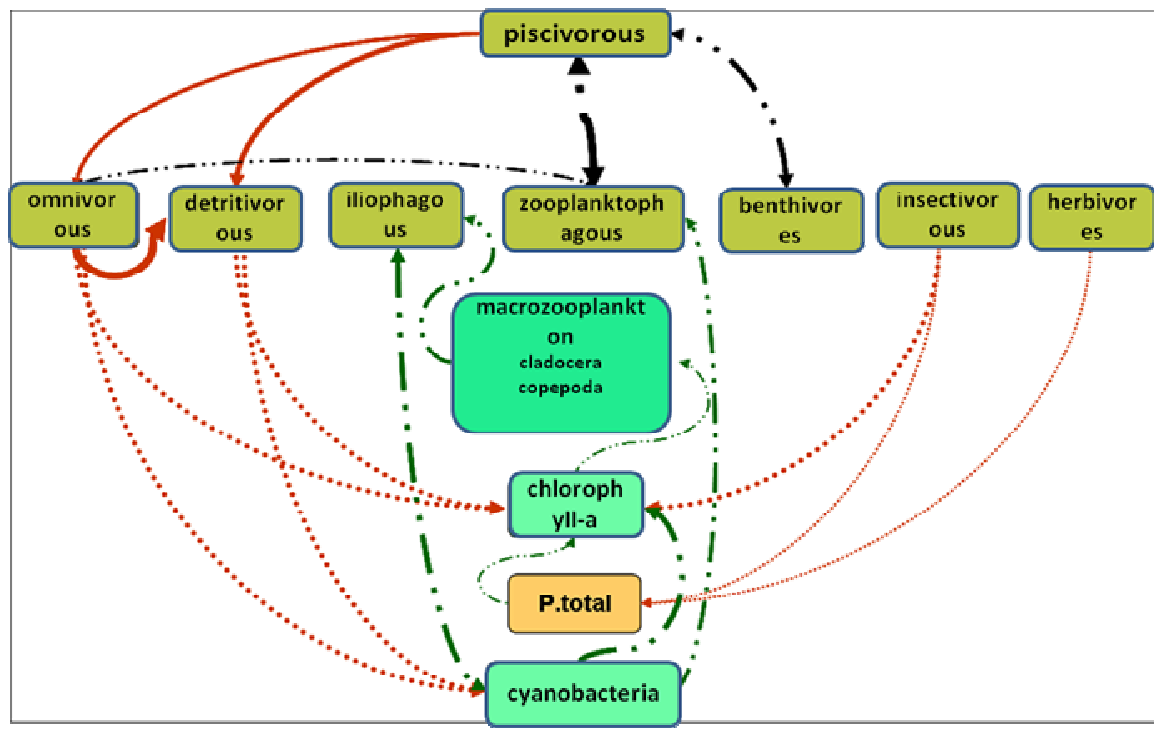

Figure 9. Food web of the Itaipu Reservoir. The arrows directed downward indicate a top-down effect, the line and dot arrows indicate a bottom-up effect, dotted arrows indicate an indirect effect, the thickness of the arrows indicate the correlation coefficient of these relations and the colors indicate the different trophic levels (fishes, zooplankton, phytoplankton and nutrients). 
cated in the subtropical region, receives large tributaries (rivers Paranapanema, Tietê and Grande) from the state of São Paulo and is located in the tropical region. Does the Itaipu reservoir have a strong influence of tropical systems? Does the cascade reservoirs system upstream of the Itaipu Reservoir have an influence on the dynamics of the food web? Studies with this same approach, including other variables such as macrophytes biomass and predatory birds and benthic macro invertebrates, may help to elucidate this issue.

According [1], the food web of a reservoir is represented by several groups of organisms according to their lifestyles and feeding habits. The groups of organisms are mutually related to each other mainly by their feeding habits, by allelopathic reactions (by chemical compounds released by organisms), by the behavioral reactions and by the recycling of nutrients. The authors stress the importance of knowing aquatic organisms and the food web of a reservoir, in which the presence or absence of certain species and their food web serves as a long-term indicator of water quality.

\subsection{Inference of Fish Yield}

Predictive models to estimate the production and fish yield are commonly used in African and North American lakes and reservoirs [132,61,62,42,133,134].

Numerous independent variables can be used to predict indices that explain fishing yield in lakes and reservoirs, through biotic and abiotic variables (reservoir area, average depth, alkalinity, air temperature, water transparency, dissolved solids, morfoedaphic index-MEI, chlorophyll and phytoplankton biomass, primary production, benthos, macrophytes, fish biomass) that can be tested in univariate and multivariate models.

According to the results found, the model predicts that increasing concentrations of cyanobacteria involves depletion of fish catches in the Itaipu Reservoir. The correlation coefficient explained $68 \%(p=0.05)$. [135], in a study of 29 reservoirs of the state of Paraná, developed a multivariate model, in which fish biomass was explained by the chlorophyll-a and zooplankton variables. The authors emphasize that the bottom-up effect in these environments is explained by the positive relationship with chlorophyll-a and negative with zooplankton.

The inference of fish yield calculated by the equation of [61] was $8.1 / \mathrm{kg} / \mathrm{ha} / \mathrm{year}$ and this result is similar to that obtained by [49], who found an average of 7.9 $\mathrm{kg} / \mathrm{ha} /$ year for the years 2000 to 2004 , indicating that an analysis for the formulation of a specific model for the reservoir can reveal accurate predictions.

It is important to stress that these models provide a quick estimate, but the continued monitoring of professional and amateur fishing over a long period of time (as it is currently done by Itaipu) are of utmost importance for the understanding of fishing yield, as well as the dynamics of the structure of species of the reservoir.

The relationship between MEI and water transparency was verified by regression analysis. This relationship indicates that the increase in water transparency influences the depletion of MEI $(\mathrm{R}=0.687, \mathrm{P} \leq 0.001, \mathrm{~F}=$ $62.59)$, and the relationship between chlorophyll-a and the MEI is inverse to water transparency $(\mathrm{R}=0.325, \mathrm{P}=$ $0.005, F=8.268)$. The same behavior of relationships was also observed in Indian reservoirs [128], in which water transparency had a negative effect and chlorophyll-a, positive. These relationships indicate that the analysis of the MEI and a series of fish production data can generate a predictive model of fishing yield for the reservoir. An analysis using the morphoedaphic index and catches may reveal a more accurate model for fishing yield. According to [136], estimates on abundance and fishing yield are necessary as tools for solving problems related to fisheries management in reservoirs.

Another aspect to be considered is that all analyses of water quality variables were performed with data collected from the water surface. This may explain why the model created that showed closest figures regarding the catch was one that included data from cyanobacteria. This group of algae is dominant in the superficial regions of lakes and reservoirs, and the action of winds is a determining factor for the appearance of blooms [63].

The lack of detailed information on fish production prevented the creation of more efficient and powerful predictive models. This line of research is of great value, and good models that can infer the production and fishing yield in lakes and reservoirs are tools that can be used by the agencies responsible for aquatic resources management in Brazil.

\section{Conclusions}

Evaluating the results, it was possible to conclude that the trophic cascade hypothesis in the Itaipu Reservoir showed both top-down and bottom-up effects, and the negative effect of piscivores was seen only in the trophic level below, and the effect of the other levels were positive, featuring a stronger bottom-up force. The cycle of the food web seems to be explained by the omnivore and detritivore biomasses, an effect observed in tropical and subtropical environments, being of extreme importance in the (indirect) relationships, and determining the controlling forces of primary productivity in the reservoir. The limnological variables in the Itaipu Reservoir showed a pattern of spatial (horizontal) and temporal variations that is strongly dependent on the hydrological regime. The forms of nutrients influenced the development of primary productivity (as measured by chlorophyll-a), and while the TKN and total phosphorus had a 
positive effect, ammonia nitrogen and nitrate had a negative effect. The models created answer how these variables influence the concentration of chlorophyll-a. The negative effect of turbidity and suspended solids on water transparency was confirmed by means of linear regression analyses, and the generated models explain around $61 \%$ of this effect at a high significance level.

The transition zone was the one with the highest concentrations of nutrients, higher chlorophyll concentration, higher density of cyanobacteria and zooplankton and a higher trophic degree, characterizing eutrophic conditions, but, on average, it was considered mesotrophic.

The average results of the trophic state indices indicate an oligotrophic status for the entire reservoir as well as for the riverine, transition and lacustrine zones separately. It is possible to verify, during years of study, that the process of eutrophication of the reservoir is occurring slowly, but some high values found highlight larger inputs of nutrients.

The increase in primary productivity, expressed by chlorophyll-a, was explained by increased levels of total phosphorus in which the models were significant and responded for more than $40 \%$ of this ratio.

Cyanobacteria were dominant in the Itaipu Reservoir, and their highest values were obtained in the transition zone. Increasing concentrations of chlorophyll-a were positive and significantly related to the greater density of cyanobacteria. Cyanobacteria also suffered the influences of abiotic variables such as water transparency, turbidity, suspended solids and TKN, and the latter had a negative effect on the development of algae. The model created explains $57 \%$ of these relationships.

The fishes that exercised the greatest control over cyanobacteria were omnivores and detritivores. The models explain about $88 \%$ of the relationship pressure of these groups of fish on these algae. Zooplanktivorous fishes did not present any controlling effect on the densities of zooplankton, and their development was positively related to cyanobacteria, indicating growth of the latter. The Prochilodus lineatus was the only species to compose the iliophagous group, having a positive effect regarding chlorophyll-a, and the concentrations of the latter increased with the increase of iliophagous fish biomass.

Omnivores and detritivores were the trophic guild groups that showed a controlling effect on the cyanobacteria and chlorophyll-a, indicating that when these groups of fish increase, they reduce primary productivity in the reservoir. The piscivores may be presenting a negative effect on water quality of the Itaipu Reservoir, in which the control effect is exercised by the biomass of omnivores and detritivores.

The fish yieldn was estimated by the relation with cyanobacteria concentration, and this was the variable that best explained this prediction, in $68 \%$. The use of the morfoedaphic index (MEI), with the recorded catch data, can generate predictive models that estimate the fishing yield in the Itaipu Reservoir. The relations of MEI with chlorophyll-a and water transparency indicate that this index may be a good predicting factor for future fish captures.

\section{Aknowledgements}

This paper is part of a $\mathrm{PhD}$. Thesis reported by the main author. We would like to thank CAPES for the financial support and CRHEA for the use of facilities. We thank Itaipu Binacional for making available the data that was used in this work.

\section{REFERENCES}

[1] G. M. Straškraba and J. G. Tundisi, "Diretrizes Para o Gerenciamento de Lagos," IIE-Instituto Internacional de Ecologia, 2000.

[2] J. Hrbáček, M. Dvoráková, V. Korínek and L. Procházková, "Demonstration of the Effect of the Fish Stock on the Species Composition of Zooplankton and the Intensity of the Whole Plankton Association," Verhandlungen des Internationalen Verein Limnologie, Vol. 14, 1961, pp. 192-195.

[3] J. L. Brooks and S. I. Dodson, "Predation, Body Size and Composition of Plankton," Science, Vol. 150, No. 3692, 1965, pp. 28-35. doi:10.1126/science.150.3692.28

[4] J. Shapiro, V. Lamarra and M. Lynch, "Biomanipulation, an Ecosystem Approach to Lake Restoration," In: P. Brezonik and L. Fox, Eds., Proceedings of a Symposium on Water Quality Management Through Biological Control, University Press of Florida, Gainesville, 1975, pp. 85-96.

[5] S. R. Carpenter and J. F. Kitchell, "The Trophic Cascade in Lakes,” Cambridge University Press, Cambridge, 1993.

[6] R. DeMelo, R. France and J. D. McQueen, "Biomanipulation: Hit or Myth?" Limnology and Oceanography, Vol. 37, No. 1, 1992, pp. 192-207.

[7] M. T. Brett and C. R. Goldman, "A Meta-Analysis of the Freshwater Trophic Cascade," Proceedings of the $\mathrm{Na}$ tional Academy of Sciences of the United States of America, Vol. 93, No. 15, 1996, pp. 7723-7726. doi:10.1073/pnas.93.15.7723

[8] M. T. Brett and C. R. Goldman, "Consumer versus Resource Control in Freshwater Pelagic Food Webs," Science, Vol. 275, 1997, pp. 354-386.

[9] J. D. McQueen, J. R. Post and E. L. Mills, "Trophic Relationships in Freshwater Pelagic Ecosystems," Canadian Journal of Fisheries and Aquatic Sciences, Vol. 43, No. 8, 1986, pp. 1571-1581. doi:10.1139/f86-195

[10] M. S. Arcifa, T. G. Northcote and O. Froehlich, "FishZooplankton Interactions and Their Effects on Water Quality of a Tropical Brazilian Reservoir," Hydrobiologia, Vol. 139, No. 1, 1986, pp. 49-58. doi:10.1007/BF00770241 
[11] X. T. Lazzaro, “A Review of Plankitivorous Fishes: Their Evolution, Feeding Behavior, Selectivity, and Impacts," Hydrobiologia, Vol. 146, No. 2, 1987, pp. 97-167. doi:10.1007/BF00008764

[12] X. T. Lazzaro, "Feeding Convergence in South American and African Zooplaktivorous Cichlids Geophagus Brasiliensis and Tilapia Rendalli," Environmental Biology of Fishes, Vol. 31, No.3, 1991, pp. 283-293. doi:10.1007/BF00000693

[13] J. Pijanowska and A. Prejs, "Food-Web Manipulation in Shallow, Eutrophic Lakes: Bridging the Gap between the Role-Lake Approach and Behavioral and Demographic Studies," Hydrobiologia, Vol. 342-343, 1997, pp. 305310. doi:10.1023/A:1017072332572

[14] E. Jeppensen, J. P. Jensen, M. Sondergaard, T. Lauridsen, L. J. Pedersen and L. Jensen, "Top-Down Control in Freshwater Lakes: The Role of Nutrient State, Submerged Macrophytes and Water Depth," Hydrobiologia, Vol. 342-343, 1997, pp. 151-164. doi:10.1023/A:1017046130329

[15] J. D. McQueen, "Manipulating Lake Community Structure: Where Do We Go from Here?" Freshwater Biology, Vol. 23, No. 3, 1990, pp. 613-620. doi:10.1111/j.1365-2427.1990.tb00299.x

[16] K. D. Hambright, "Morphological Constraints in the Piscivore-Planktivore Interaction: Implications for the Trophic Cascade Hypothesis," Limnology and Oceanography, Vol. 39, No. 4, 1994, pp. 897-912. doi:10.4319/10.1994.39.4.0897

[17] D. J. McQueen, R. France and C. Kraft, "Confounded Impacts of Planktivorus Fish on Freshwater Biomanipulations," Archiv für Hydrobiologie, Vol. 125, No. 1, 1992, pp. 1-24.

[18] X. T. Lazzaro, "Do the Trophic Cascade Hypothesis and Classical Biomanipulation Approaches Apply to Tropical Lakes/Reservoirs?" Verhandlungen des Internationalen Verein Limnologie, Vol. 26, 1997, pp. 719-730.

[19] R. W. Drenner, K. L. Gallo, R. M. Baca and J. D. Smith, "Synergistic Effects of Nutrients Loading and Omnivorus Fish on Phytoplankton Biomass," Canadian Journal of Fisheries and Aquatic Sciences, Vol. 55, No. 9, 1998, pp. 2287-2296. doi:10.1139/f98-095

[20] F. L. M. Starling, "Development of Biomanipulation Strategies for the Remediation of Eutrophication Problem in a Urban Reservoir-Lago Paranoá," PhD Thesis, University of Stirling, Scotland, 1998.

[21] M. Perrow, M. L. Meijer, P. Dawidowicz and H. Coops, "Biomanipulation in Shallow Lakes: State of the Art," Hydrobiologia, Vol. 342-343, 1997, pp. 355-365. doi:10.1023/A:1017092802529

[22] J. Shapiro and J. Wright, "Lake Restoration by Biomanipulation: Round Lake, Minnesota, the First 2 years," Freshwater Biology, Vol. 14, No. 4, 1984, pp. 371-383.

[23] S. R. Carpenter, J. F. Kitchell and J. R. Hodgson, "Cascading Trophic Interactions and Lake Productivity Fish Predation and Herbivory Can Regulate Ecosystems", BioScince, Vol. 35, No. 10, 1985, pp. 634-639. doi: $10.2307 / 1309989$

[24] L. Persson, G. Andersson, S. F. Hamirin and L. Johans- son, "Predator Regulation and Primary Production along the Productive Gradient of Temperate Lake Ecosystems," In: S. R. Carpenter, Ed., Complex Interactions in Lake Communities, Springer, New York, 1988, pp. 53-59.

[25] B. A. Faafeng and A. Brabrand, "Biomanipulation of a Small, Urban Lake: Removal of Fish Exclude Bluegreen Blooms," Verhandlungen des Internationalen Verein Limnologie, Vol. 24, 1990, pp. 597-602.

[26] M. Sondergaard, E. Jeppesen and S. Berg, "Pike (Esox lucius) Stocking as a Biomanipulation Tool 2. Effects on Lower Trophic Levels in Lake Lyng, Denmark," Hydrobiologia, Vol. 342-343, 1997, pp. 319-325. doi:10.1023/A:1017084600712

[27] A. Prejs, J. Pijanowska, P. Koperski, A. Martyniak, S. Borón and P. Hliwa, "Food-Web Manipulation in a Small, Eutrophic Lake Wirbel. Poland: Long-Term Changes in Fish Biomass and Basic Measures of Water Quality. A Case Study," Hydrobiologia, Vol. 342-343, 1997, pp. 383-386. doi:10.1023/A:1017047625303

[28] M. L. Meijer, I. DeBoois, M. Scheffer, R. Portielje and H. Hosper, "Biomanipulation in Shallow Lakes in The Netherlands: An Evaluation of 18 Case Studies," Hydrobiologia, Vol. 408-409, 1999, pp. 13-30. doi:10.1023/A:1017045518813

[29] J. Benndorf, W. Böing, J. Koop and I. Neubauer, "Top-Down Control of Phytoplankton: the Role of Time Scale, Lake Depth and Trophic State," Freshwater Biology, Vol. 47, 2002, pp. 2282-2295. doi:10.1046/j.1365-2427.2002.00989.x

[30] T. Mehner, F. Hölker and P. Kasprzak, "Spatial and Temporal Heterogeneity of Trophic Variables in a Deep Lake as Reflected by Repeated Singular Samplings," OIKOS, Vol. 108, 2005, pp. 401-409. doi:10.1111/j.0030-1299.2005.13338.x

[31] X. T. Lazzaro, M. Bouvy, R. A. Ribeiro-Filho, V. S. Oliveira, L. T. Sales, A. R. M. Vasconcelos and M.R. Mata, "Do Fish Regulate Phytoplankton in Shallow Eutrophic Northeast Brazilian Reservoirs?" Freshwater Biology, Vol. 48, 2003, pp. 649-668. doi:10.1046/j.1365-2427.2003.01037.x

[32] W. D. Davies, "Progress Report n Fisheries Development in Northeastern. II Reservoir Fisheries on Northeastern Brazil," International Center for Aquaculture Research and Development, Vol. 2, 1972, pp. 1-17.

[33] G. C. V. Gesteira, “Aspectos Biológicos Ligados à Produtividade de Pesca Nos Açudes púBlicos da áRea do 'Polígono das Secas'-Nordeste do Brasil," Dissertação (Mestrado) UFRJ, 1978, 143 p.

[34] J. W. B. Silva, "Recursos Pesqueiros de águas Interiores do Brasil, Especialmente do Nordeste," DNOCS, Diretoria de Pesca e Piscicultura, Fortaleza, Ceará, Brasil, 1981, $98 \mathrm{p}$.

[35] S. Wright, "Alguns Dados da fíSica e da Química das águas dos Açudes Nordestinos," Bol. Tec. DNOCS, Fortaleza, 39, 1981, pp. 21-32.

[36] DNOCS, "Dados Sobre a Administração da Pesca em Açudes Públicos Relativos ao Período de 1948 a 1990," DNOCS, Diretoria de Pesca e Piscicultura, Fortaleza, Ceará, 1990. 
[37] F. Molle, "Caractéristiques et Potentialités des 'Açudes' du Nordeste Brésilien," Doctoral Dissetation, Université Montpelier II, 1991, $380 \mathrm{p}$.

[38] J. J. S. Gurgel and C. H. Fernando, "Fisheries in the Semi-Arid Northeast Brazil with Special Reference to the Role of Tilapias," International Review of Hydrobiology, Vol. 79, 1994, pp. 77-94.

[39] M. P. Paiva, M. Petrere, A. J. Petenate, F. H. Nepomuceno and E. A. Vasconcelos, "Relationship between the Number of Predatory Fish Species and Fish Yield," In: Large Northeastern Brazilian Reservoirs, Rehabilitation of Freshwater Fisheries, 1994, pp. 120-129.

[40] M. Bouvy, L. B. Franca and J. P. Carmouze, "Compartimento Microbiano no Meio Pelágico de Sete Açudes do Estado de Pernambuco (Brasil)," Acta Limnologica Brasiliensia, Vol. 10, 1998, pp. 93-101.

[41] H. A. Regier and F. Henderson, "Comparative Studies on Freshwater Fisheries. FAO (Food and Agriculture Organization of the United Nations)," Fisheries Technical Paper, 1980, $46 \mathrm{p}$.

[42] R. Quiros, "Predictors of Relative Fish Biomass in Lakes and Reservoirs of Argentina," Canadian Journal of Fisheries and Aquatic Sciences, Vol. 47, 1990, pp. 928-939. doi:10.1139/f90-107

[43] R. H. Peters, "The Role of Prediction Limnology," Limnol. Oceanogr. Vol. 31, 1986, pp. 1143-1159. doi:10.4319/10.1986.31.5.1143

[44] D. A. Schlesinger and H. A. Regier, "Climatic and Morphoedaphic Indices of Fish Yields from Natural Lakes," Transactions of the American Fisheries Society. Vol. 111, 1982, pp. 1-150. doi:10.1577/1548-8659(1982)111<141:CAMIOF>2.0.CO;2

[45] R. Quirós and M. B. Boveri, "Fish Effects on Reservoir Trophic Relationships," In: J. G. Tundisi and M. Straškraba, Eds., Theoretical Reservoir Ecology and its Applications, IIE, BAC, Backuysv Publishers, 1999, pp. 529546, $592 \mathrm{p}$.

[46] D. Rejas, L. Clerck, J. Auwerkerken, P. Tak and L. Meester, "Plankton Dynamics in a Tropical Floodplain Lake: Fish, Nutrients, and the Relative Importance of Bottom-Up and Top-Down Control," Freshwater Biology, Vol. 50, 2005, pp. 52-69. doi:10.1111/j.1365-2427.2004.01306.x

[47] J. R. Borghetti, A. A. Agostinho and K. Nakatani, "Administração Pesqueira no Reservatório de Itaipu," In: J. G. Tundisi, Ed., Limnologia e Manejo de Represas, Série: Monografias em Limnologia, 1988.

[48] A. A. Agostinho and L. C. Gomes, "O manejo da pesca em Reservatórios da Bacia do Alto Rio Paraná: Avaliação e Perspectives," In: M. G. Nogueira, R. Henry and A. Jorcin, Eds., Ecologia de Reservatórios, Rima. São Carlos, 2005, $459 \mathrm{p}$

[49] A. A. Agostinho, E. K. Okada and J. Gregoris, "A Pesca no Reservatório de Itaipu: Aspectos Sócio-Econômicos e Impactos do represamento," In: R. Henry, Ed., Ecologia de Reservatórios: Estrutura, Função e Aspectos Sociais, FUNDIBIO/FAPESP, 1999, $800 \mathrm{p}$. Itaipu Binacional, www.itaipu.gov.br

[50] A. A Agostinho, V. S. Ferreira, H. F. Júlio Jr., C. V.
Minte-Vera, E. F. Oliveira, E. K. Okada, T. A. Pagioro, M. C. Roberto, H. I. Suzuki, S. M. Thomaz and F. Abujanra, "Variações Espaço-Temporais na Ictiofauna e Suas Relações com as Condições Limnológicas No Reservatório de Itaipu," Relatório Annual, Maringá, 1997, 330 p.

[51] A. A. Agostinho, H. F. Júlio Jr., L. C. Gomes, L. M. Bini and C. S. Agostinho, "Composição, Abundância e Distribuição Espaço-Temporal da Ictiofauna,” In: A. E. A. M. Vazzoler, A. A. Agostinho and N. S. Hahn., Eds., A Planície de Inundação do Alto Rio Paraná: Aspectos Físicos, Biológicos e Socioeconômicos, EDUEM, Maringá, 1997, pp. 179-208.

[52] IAP, "Estudos Limnológicos do Reservatório de Itaipu. Relatório Annual," Contrato Itaipu Binacional/Instituto Ambiental do Paraná, Curitiba, 2003, 107 p.

[53] E. F. Oliveira, C. V. Minte-Vera and E. Goulart, "Structure of Fish Assemblages along Spatial Gradients in a Deep Subtropical Reservoir (Itaipu Reservoir, BrazilParaguay border)," Environmental Biology of Fishes, Vol. 72, 2005, pp. 283-304. doi:10.1007/s10641-004-2582-5

[54] APHA (Americam Public Health Association), "Standard Methods for the Examination of Water and Wastewater," 16th Edition, Washington DC, APHA, 1985, 1134 p.

[55] E. A. Nusch, "Comparision of Different Methods for Chlorophyll and Pheopigment Determination," Archiv für Hydrobiologie-Beiheft Ergebnisse der Limnologie, Vol. 14, No. 1, 1980, pp. 14-36.

[56] R. A. Ribeiro-Filho, "Relações Tróficas e Limnológicas no Reservatório de Itaipu: Uma Análise do Impacto da Biomassa Pesqueira Nas Comunidades Planctônicas," Ph.D. Thesis, CRHEA/USP, São Carlos, 2006.

[57] A. P. Toledo Jr., M. Talartico, S. J. Chinez and E. G. Agudo, "A Aplicação de Modelos Simplificados para a Avaliação do Processo de Eutrofização em Lagos e Reservatórios Tropicais," In: Congresso Brasileiro de Engenharia Sanitária e Ambiental, 12, Comburiu, 1983, p. 34.

[58] R. A. Ryder, "A Method for Estimating the Potential Fish Production of Northtemperate Lakes," Transactions of the American Fisheries Society, Vol. 94, 1965, pp. 214-218. doi:10.1577/1548-8659(1965)94[214:AMFETP]2.0.CO;2

[59] J. M. Meleck, "Primary Productivity and Fish Yields in Tropical Lakes," Transactions of the American Fisheries Society, Vol. 105, 1976, pp. 575-580. doi:10.1577/1548-8659(1976)105<575:PPAFYI >2.0.CO;2

[60] R. T. Oglesby, "Relationships of Fish Yield to Lake Phytoplankton Standing Crop, Production and Morphoedaphic Factors," Journal of Fisheries Research Board of Canada, Vol. 34, No. 12, 1977, pp. 2271-2279. doi:10.1139/f77-305

[61] J. G. Tundisi, "Distribuição Espacial, Sequência Temporal e Ciclo Sazonal do Fitoplâncton em Represas: Fatores Limitantes e Controladores," Revista Brasileira de Biologia, Vol. 50, No. 4, 1990, pp. 937-955.

[62] K. W. Thornton, "Perspectives on Reservoir Limnology," In: K. W. Thornton, B. L. Kimmel, F. E. Payne, Eds., Reservoir Limnology: Ecological Perspectives, A WileyInterscience, New York, 1990, pp. 1-13. 
[63] S. S. Stivari, A. P. Oliveira and J. Soares, "On the Climate Impact of the Local Circulation in the Itaipu Lake Area," Climatic Change, Vol. 72, 2005, pp. 103-121. doi:10.1007/s10584-005-5923-2

[64] C. E. M. Tucci, "Escoamento Superficial,” In: C. E. M. Tucci, Ed., Hidrologia: Ciência e Aplicação, $3^{a}$ edição, Editora da UFRGS/ ABRH, Porto Alegre, RS, 2002.

[65] M. F. F. Ferrareze, M. G. Nogueira and N. C. Vianna, "Transporte de Nutrientes e Sedimentos no rio Paranapanema (SP/PR) e Seus Principais Tributários nas Estações seca e Chuvosa," In: M. G. Nogueira, R. Henry and A. Jorcin, Eds., Ecologia de Reservatórios, Rima, São Carlos, 2005, 459 p.

[66] R. M. Pinto-Coelho, L. M. A. Azevedo, P. E. V. Rizzi, J. F. Bezerra-Neto and M. E. Rolla, "Origens e Efeitos do Aporte Externo de Nutrientes em um Reservatório Tropical de Grande Porte: Reservatório de São Simão (MG/ GO)," In: M. G. Nogueira, R. Henry and A. Jorcin, Eds., Ecologia de Reservatórios, Rima, São Carlos, 2005, 459 p.

[67] M. G. Nogueira, A. Jorcin, N. C. Vianna and Y. C. T. De Britto, "Reservatório em Cascata e os efeitos na Limnologia e Organização das Comunidades Bióticas (Fitoplâncton, Zooplâncton e Zoobentos) - Um Estudo de Caso no Rio Paranapanema (SP/PR)," In: M. G. Nogueira, R. Henry and A. Jorcin, Eds., Ecologia de Reservatórios, Rima, São Carlos, 2005, 459 p.

[68] F. A. Esteves, "Fundamentos de Limnologia," Editora Interciência/FINEP, Rio de Janeiro, 1988, 575 p.

[69] B. Jezierska, "Fish metabolism," Polish Ecological Studies, Vol. 5, No. 3, 1979, pp. 43-51.

[70] T. Iwakuma, H. Hayashi, I. Yasuda, T. Hanazato and K. Takada, "Impact of Whitefish on am Enclosure Ecosystem in a Shallow Eutrophic Lake: Changes in Nutrients Concentrations, Phytoplankton and Zoobenthos," Hydrobiologia, Vol. 200-201, 1990, pp. 141-152. doi:10.1007/BF02530335

[71] G. Anderson, W. Granéli and J. Stenson, "The Influence of Animals on Phosphorus Cycling in Lake Ecosystems," Hydrobiologia, Vol. 170, 1988, pp. 267-284. doi:10.1007/BF00024909

[72] A. Persson, "Phosphorus Release by Fish in Relation to External and Internal Load in a Eutrophic Lake," Limnology and Oceanography, Vol. 42. No. 3, 1997, pp. 577583. doi:10.4319/10.1997.42.3.0577

[73] L. F. Andrade, R. F. Brunkow, C. F. Xavier and L. L. Domingues, "Fitoplâncton e Características Físico-Químicas do Reservatório de Itaipu," In: Tundisi J. G. Ed., Limnologia e Manejo de Represas, Monografias em Limnologia, Série, 1988.

[74] T. A. Pagioro, M. C. Roberto, S. M. Thomaz, A. S. Pierini and M. Taka, "Zonação Longitudinal das Variáveis Limnológicas Abióticas em Reservatórios,” In: L. Rodrigues, S. M. Thomaz, A. A. Agostinho and L. C. Gomes, Eds., Biocenose em Reservatórios: Padrões espaciais e temporais, Rima Editora, São Carlos, 2005.

[75] R. G. Wetzel, "Reservoir Ecosystems: Conclusions and Speculations," In: K. W. Thornton, B. L. Kimmel and F. E. Payne, Eds., Reservoir Limnology: Ecological Per- spectives, A Wiley-Interscience, New York, 1990, pp. 227-238.

[76] R. Henry, “Amônia ou Fosfato Como Agente Estimulador do Crescimento do Fitoplâncton na Represa de Jurumurim (Rio Paranapanema, SP)?" Revista Brasileira de Biologia, Vol. 50, No. 4, 1990, pp. 883-892.

[77] D. J. McQueen, M. R. S. Johannes, J. R. Post, T. J. Stewart and D. R. S. Lean, "Biomanipulation and Community Structure at Lake St. George, Ontario. Canada," Verhandlungen des Internationalen Verein Limnologie, Vol. 24, 1990, pp. 335-338.

[78] R. W. Drenner, J. D. Smith and S. T. Threlkeld, "Lake Trophic State and the Limnological Effects of Omnivorus Fish," Hydrobiologia, Vol. 319, 1996, pp. 213-223. doi:10.1007/BF00013734

[79] M. C. Calijuri and J. G. Tundisi, "Limnologia Comparada das Represas do Lobo (Broa) e Barra Bonita-Estado de São Paulo: Mecanismos de Funcionamento e Bases para o Gerenciamento," Revista Brasileira de Biologia, Vol. 50, No. 4, 1990, pp. 893-913.

[80] E. E. Souza-Filho and J. C. Stevaux, "Geologia e Geomorfologia do Complexo do rio Baía, Curutuba, Ivinheima," In: A. E. A. M. Vazzoler, A. A. Agostinho and N. S. Hahn, Eds., A Planície de Inundação do Alto Rio Paraná: Aspectos Físicos, Biológicos e Socioeconômicos, EDUEM, Maringá, 1997, pp. 179-208.

[81] R. G. Wetzel, "Limnology: Lakes and River Ecosystems," Academic Press, San Diego, 2001.

[82] L. H. Zanata, "Heterogeneidade Ambiental no Reservatório de Salto Grande (Americana-SP) Com ênfase na Distribuição das Populações de Cladocera," Master Thesis, CRHEA/EESC/USP, São Carlos, 1999, 218 p.

[83] R. A. Ribeiro Filho, "Caracterização de Dietas Alimentares de Peixes Predadores em Açudes de Pernambuco e no Lago Paranoá (Brasília-DF)," Monografia Universidade Federal Rural de Pernambuco, Recife, 1999, 52 p.

[84] F. Pedro, “Alimentação e Comportamento Predatório do tucunaré Cichla ocellaris, Bloch \& Schneider, 1801 (Osteichihyes: Cichlidae)," Master Thesis, UFPB, João Pessoa, 1995, $132 \mathrm{p}$.

[85] R. A. Vollenweider, "A Manual on Methods for Measuring Primary Production in Aquatic Environments," 2nd Edition, Blackwell Scientific Publications (IBP Handbook, 12), London, 1974, 225 p.

[86] J. J. R. Ramirez, "Variação Especial Vertical e Nictimeral da Estrutura da Comunidade Fitoplanctônica e Variáveis Ambientais em Quatro Dias de Amostragem de Diferentes épocas do ano na Lagoa das Garças, São Paulo," PhD. Thesis, USP, São Paulo, 1996, 300 p.

[87] F. L. M. Starling and A. J. A. Rocha, "Experimental Study of Planktivorous Fishes on Plankton Community and Eutrophication of a Tropical Brazilian Reservoir," Hydrobiologia, Vol. 200-201, 1990, pp. 5081-5591. doi:10.1007/BF02530375

[88] C. C. Figueredo, "Efeitos da Tilápia (Oreochomis Niloticus) Nas Características fíSicas e Químicas e Estrutura da Comunidade Fitoplanctônica do Reservatório da Usina Hidroelétrica de Furnas (MG)," Master Thesis, UFMG, 
Belo Horizonte, 2000, 150 p.

[89] R. A. Ribeiro Filho, "Estudo Experimental de Biomanipulação: Análise dos Impactos Ambientais de Duas Espécies de Predadores no Controle de Tilápia no Lago Paranoá (Brasília-DF)," Master Thesis, CRHEA/EESC/ USP, São Carlos, 2002.

[90] A. Minillo, “Análise da Distribuição, Densidade e ToxiciDade de Florações de Cianobactérias e Suas Toxinas nos Reservatórios do Médio e Baixo rio Tietê (SP) e Relação com as Características Limnológicas do Sistema," Ph.D. Thesis, CRHEA/EESC/USP, São Carlos, 2005, 394 p.

[91] S. A Townsend, "The Seasonal Pattern of Dissolved Oxygen an Hypolimnetic Deoxygenation, in Two Tropical Australian Reservoir," Lakes \& Reservoir: Research and Management, Vol. 4, No. 1, 1999, pp. 41-53.

[92] CETESB, "Parâmetros Para Análise da Qualidade de água," 2006.

http://www.cetesb.sp.gov.br/Agua/rios/variáveis.asp

[93] J. D. McQueen, "Freshwater Food Web Biomanipulation: A Powerful Tool for Water Quality Improvement, but Maintenance Is Required," Lakes \& Reservoirs: Research and Management, Vol. 3, 1998, pp. 83-94. doi:10.1111/j.1440-1770.1998.tb00035.x

[94] J. M. Hanson and W. C. Legget, "Empirical Prediction of Fish Biomass and Weight," Canadian Journal of Fisheries and Aquatic Sciences, Vol. 39, 1982, pp. 257-263. doi:10.1139/f82-036

[95] E. Jeppensen, J. P. Jensen, M. Søndergaard, T. Lauridsen and F. Landkildehus, "Trophic Structure, Species Richness and Biodiversity in Danish Lakes: Changes along a Phosphorus Gradient," Freshwater Biology, Vol. 45, No. 2, 2000, pp. 201-218.

[96] R. G. Wetzel, "Limnologia," Fundação Calouste Gulbenkian, 1993, $1011 \mathrm{p}$.

[97] L. M. Bini, "Monitoramento da Qualidade da água no Reservatório de Itaipu," Relatório Final-AS CT/0044/2002Itaipu Bionacional, Junho 2003, 34 p.

[98] C. S. Reynolds, "The Ecology of Freshwater Phytoplankton-Cambrige Studies in Ecology," Cambrige University Press, Cambrige, 1984, 384 p.

[99] R. Kurmayer and J. Wanzenbock, "Top-Down Effects of under Yearling Fish on a Phytoplankton Community," Frehswater Biology, Vol. 36, 1996, pp. 599-609. doi:10.1046/j.1365-2427.1996.00127.x

[100] H. S. Karjalainen, S. Seppala and M. Walls, "Nitrogen, Phosphorus and Daphinia Grazing in Controlling Phytoplankton Biomass and Composition-An Experimental Study," Hydrobiologia, Vol. 363, 1998, pp. 309-321.

[101] T. A. Pagioro and S. M. Thomaz, "Longitudinal Patterns of Sedimentation in a Deep Monomitc Subtropical Reservoir Itaipu (Brazil-Paraguay)," Archiv für Hydrobiologie, Vol. 154, No. 3, 2002, pp. 515-528.

[102] V. A. Lamarra, "Digestive Activities of Carp as a Major Contributor to the Nutrient Loading of Lakes," Verhandlungen des Internationalen Verein Limnologie, Vol. 19, 1975, pp. 2461-2468.

[103] J. V. Grando, “Considerações Sobre o Estagio Atual da Ictiofauna e Aspectos Alimentares de Quatro Espécies de
Peixes do Lago Paranoá, Brasília-DF. Brasília," Master Thesis, Universidade de Brasília, Brasília, 1989.

[104] J. M. A. Pereira and R. A. Ribeiro Filho, "Efeitos da Excreção de Tilápias (Tilapia rendali e Oreochromis Niloticus) em Reservatórios e Viveiros de Piscicultura," In: E. L. G. Espíndola and E. Wendland, Eds., Bacia Hidrográfica: Diversas Abordagens em Pesquisa, Rima, São Carlos, 2004, 412 p. doi:10.1007/BF02538504

[105] R. Henry and A. C. Simão "Aspectos Sazonais da Liberação Potencial por N, P e Fe no Fitoplâncton na Represa de Barra Bonita (Rio Tietê, SP)," Revista Brasileira de Biologia, Vol. 48, No. 1, 1990, pp. 1-14.

[106] T. A. Pagioro, S. M. Thomaz and M. C. Roberto, "Caracterização Limnológica Abiótica dos Reservatórios," In: L. Rodrigues, S. M. Thomaz, A. A. Agostinho and L. C. Gomes, Eds., Biocenose em Reservatórios: Padrões Espaciais e Temporais, Rima Editora, São Carlos, 2005.

[107] J. G. Tundisi, "Limnologia de Represas Artificiais," Boletim de Hidráulica e Saneamento, EESC-USP, Vol. 11, No. 1, 1986, pp. 1-46.

[108] C. S. Reynolds, "The Response of Phytoplankton Communities to Changing Lake Environments," Schweiz Z Hydrobiologie, Vol. 49, No. 2, 1987. pp. 220-236.

[109] T. Matsumura-Tundisi, S. Neumann-Leitão, L. S. Aguena and J. Miyahara, "Eutrofização da Represa de Barra Bonitas: Estrutura e Organização da Comunidade de Rotifera," Revista Brasileira de Biologia, Vol. 50, No. 4, 1990, pp. 923-935.

[110] L. F. M. Velho, F. A. Lansac-Tôha and C. C. Bonecker, "Distribuição Longitudinal da Comunidade Zooplanctônica em Reservatórios," In: L. Rodrigues, S. M. Thomaz, S. S. Agostinho and L. C. Gomes, Eds., Biocenose em Reservatórios: Padrões Espaciais e Temporais, Rima Editora, São Carlos, 2005.

[111]E. L. G. Espíndola, T. Matsumura-Tundisi and A. C. Rietzler, "Heterogeneidade Espacial do Reservatório de Tucuruí (Estado do Pará, Amazônia, Brasil) e a Distribuição das Espécies Zooplanctônicas," Revista Brasileira de Biologia, Vol. 60, No. 2, 2000, pp. 179-194.

[112] G. R. Marzolf, "Reservoirs as Environments for Zooplankton," In: K. W. Thornton, B. L. Kimmel and F. E. Payne, Eds., Reservoir Limnology: Ecological Perspectives, John Wiley \& Sons, New York, 1990, pp. 195-208.

[113]F. A. Lansac-Tôha, L. F. M. Velho and C. C. Bonecker, "Estrutura da Comunidade Zooplanctônica Antes e após a Formação do Reservatório de Corumbá-GO," In: R. Henry, Ed., Ecologia de Reservatório: Estrutura, Função e Aspectos, FUNDIBIO/ FAPESP, Botucatu, 1999.

[114]F. A. Lansac-Tôha, C. C. Bonecker and L. F. M. Velho, "Estrutura da Comunidade Zooplanctônica em Reservatórios," In: L. Rodrigues, S. M. Thomaz, A. A. Agostinho and L. C. Gomes, Eds., Biocenose em Reservatórios: Padrões Espaciais e Temporais, Rima Editora, São Carlos, 2005.

[115] R. de Bernardi and G. Giussani, "Diretrizes para o Gerenciamento de Lagos," Biomanipulação Para o Gerenciamento de Lagos e Reservatórios, Vol. 7, 2001, 221 p.

[116] O. Rocha, S. Sendacz and T. Matsumura-Tundisi, "Com- 
position, Biomass and Productivity of Zooplankton in Natural Lakes and Reservoirs of Brazil," In: J. G.Tundisi, C. E. M. Bicudo and T. Matsumura-Tundisi, Eds., Limnology in Brazil, ABC/SLB, Rio de Janeiro, 1995, pp. 151-165.

[117]E. C. Blancher, "Zooplankton-Trophic Relationship in Some North and Central Florida Lakes," Hydrobiologia, Vol. 109, 1984, pp. 251-263. doi:10.1007/BF00007743

[118] E. K. Okada, "Gradientes Espaço-Temporais na Pesca Artesanal no Reservatório de Itaipu," Ph.D. Thesis, UEM/ NUPELIA, Maringá, 2001.

[119] J. R. Hodgson, X. He and J. F. Kitchell, "The Fish Populations," In: S. R. Carpenter and J. F. Kitchell, Eds., The Trophic Cascade in Lakes, Cambridge University Press, Cambridge, 1996, 385 p.

[120] M. E. Power, "Effects of Fish in River Food Webs," Science, Vol. 250, 1990, pp. 811-814. doi:10.1126/science.250.4982.811

[121] N. G. Hairston, "Does Food Web Complexity Eliminate Trophic-Level Dynamics?" American Naturalist, Vol. 149, No. 5, 1997, pp. 1001-1007. doi:10.1086/286035

[122] R. D. Gulati, "Manipulação das Populações de Peixes Visando a Recuperação de Lagos Eutrofizados em Regiões Temperadas," In: R. de Bernardi and G. Giussani, Biomanipulação para o Gerenciamento de Lagos e Reservatórios, Cap, Vol. 3, 2001, pp. 33-51.

[123] S. R. Carpenter, J. J. Cole, J. R. Hodgson, J. F. Kitchell, M. L. Pace, D. Bade, K. L. Cottingham, T. E. Essington, J. N. Houser and A. E. Schindler, "Trophic Cascades, Nutrients, and Lake Productivity: Whole-Lake Experiments," Ecological Monographs, Vol. 71, No. 2, 2001, pp. 163-186.

doi:10.1890/0012-9615(2001)071[0163:TCNALP]2.0.CO;2

[124] R. C. Lathrop, B. M. Johnson, T. B. Johnson, M. T. Vogelsang, S. R. Carpenter, T. R. Hrabik, J. F. Kitchell, J. J. Magnuson, L. G. Rudstam and R. S. Stewart, "Stocking Piscivores to Improve Fishing and Water Clarity: A Synthesis of the Lake Mendota Biomanipulation Project," Freshwater Biology, Vol. 47, 2002, pp. 2410-2424. doi:10.1046/j.1365-2427.2002.01011.x

[125] T. Bell, W. E. Neill and D. Schluter, "The Effect of Temporal Scale on the Outcome of Trophic Cascade Experiments," Oecologia, Vol. 134, 2003, pp.578-586.

[126] L. A. Hansson, M. Gyllstroem, A. Staahl-Delbanco and S. Svensson "Responses to Fish Predation and Nutrients by Plankton at Different Levels of Taxonomic Resolution," Freshwater Biology, Vol. 49, 2004, pp. 1538-1550. doi:10.1111/j.1365-2427.2004.01291.x

[127] E. T. Borer, E. W. Seabloom, J. B. Shurin, K. E. Anderson, C. A. Blanchette, B. Broitman, S. D. Cooper and B. S. Halpern, "What Determines the Strength of a Trophic Cascade?” Ecology, Vol. 86, No. 2, 2005, pp. 528-537. doi:10.1890/03-0816

[128] F. Scasso, N. Mazzeo, J. Gorga, J. Kruk, G. Lacerot, J. Clemente, D. Fabián and S. Bonilla, "Limnological Changes in a Sub-Tropical Shallow Hypertrophic Lake during Its Restoration: Two Years of a Whole-Lake Experiment," Aquatic Conservation: Marine and Freshwater Ecosystems, Vol. 11, 2001, pp. 31-44. doi:10.1002/aqc.420

[129] M. R. Hasan, M. A. W. Mondal, M. I. Miah and M. G. Kibria, "Water Quality Study of Some Selected Oxbow Lakes with Special Emphasis on Chlorophyll-a," In: S. S. de Silva, Ed., Reservoir and Culture-Based Management Fisheries, Biology and Management, 2001.

[130] E. Jeppensen, M. Søndergaard, N. Mazzeo, M. Meerhoff, C. C. Branco, V. Huscar and F. Scasso, "Lake Restoration and Biomanipulation in Temperate Lakes: Relevance for Subtropical and Tropical Lakes," In: M. V. Reddy and B. Moss, Eds., Tropical Eutrophic Lakes: The Restoration and Management, Science Publishers, 2005.

[131] K. D. Hambright, R. W. Drenner and S. R. McComas, "Gape-Limited Piscivores, Planktivores Size Refuges, and the Trophic Cascade Hypothesis," Archiv für Hydrobiologie, Vol. 121, No. 4, 1991, pp. 389-404.

[132] A. Brabrand, B. Faafeng and J. P. M. Nilssen, "Relative Importance of Phosphorus Supply to Phytoplankton Production: Fish Excretion versus External Loading," Canadian Journal of Fisheries and Aquatic Sciences, Vol. 47, 1990, pp. 364-372. doi:10.1139/f90-038

[133] F. Henderson and R. L. Welcome, "The Relationship of Yield to Morpho-Edaphic Index and Number of Fishermen in African Fisheries," Committee for Inland Fisheries of Africa, Occas, Pap. 1, FAO, Rome, 1974, 19 p.

[134] B. E. Marshall, "Predicting Ecology and Fish Yields in African Reservoirs from Preimpoundment PhysicoChemical Data," FAO, CIFA Technical Paper 12, 1984, $36 \mathrm{p}$.

[135] G. G. Sass and J. F. Kitchell, "Can Growth Be Used as a Surrogate Measure of Walleye (Sunder Vitreus) Abundance Change?" Canadian Journal of Fisheries and Aquatic Sciences, Vol. 62, No. 2, 2005, pp. 2159-2168. doi:10.1139/f05-129

[136] P. A. Piana, K. D. G Da Luz, F. M. Pelicice, R. S. Costa, L. C. Gomes and A. A. Agostinho, "Predição e Mecanismos Reguladores da Biomassa de Peixes em Reservatórios," In: L. Rodrigues, S. M. Thomaz, A. A. Agostinho and L. C. Gomes, Eds., Biocenose em Reservatórios: Padrões Espaciais e Temporais, Rima Editora, São Carlos, 2005.

[137] M. H. Marouelli, R. H. S. Emeric, C. G. B. Cavalcanti, E. Rutkowski, M. E. C. Sales, S. M. A Segundo, G. D. Forattini, R. H. Pera and I. Castro, "Bases para uma Manejo Racional de Reservatórios. Administração Pesqueira no Reservatório de Itaipu," In: J. G. Tundisi, Ed., Limnologia e Manejo de Represas, Monografias em Limnologia, Série, 1988.

[138] K. F. Roche, O. Rochaand, E. L. G. Espíndola, "Impacto do Acará, Geophagus Brasiliensis (CICHLIDAE), No Plâncton da Represa do Broa: Um Experimento Usando Mesocosmos," In: K. F. Roche and O. Rocha, Eds., Ecologia Trófica de Peixes com Ênfase na Planctivoria nos Ambientes Lênticos de água doce no Brasil, Rima, São Carlos, 2005, 136 p.

[139] F. Abujanra and A. A. Agostinho, "Dieta de Hypophtalmus Edentatus (Spix 1829) (Osteichthyes, Hypophtalmidae) e Variações de seu Estoque no Reservatório de Itaipu," Acta Scientiarum, Vol. 24, No. 2, 2002, pp. 401- 
410.

[140] F. M. Pelicici, F. Abujanra, R. Fugi, J. D. Latini, L. C. Gomes and A. A. Agostinho, "A Piscivoria Controlando a Produtividade em Reservatórios: Explorando o Mecanismo Top Down," In: L. Rodrigues, S. M. Thomaz, A. A Agostinho and L. C. Gomes, Eds., Biocenose em Reservatórios: Padrões Espaciais e Temporais, Rima Editora,
São Carlos, 2005.

[141] R. M. Baca and R. W. Drenner, "Do the Effects of Piscivorous Largemouth Bass Cascade to the Plankton?" Hydrobiologia, Vol. 316, No. 2, 1995, pp. 139-151. doi:10.1007/BF00016895 